\title{
A Chiral Biaryl P,N-Ligand for Asymmetric Catalysis
}

Concept:<smiles>c1ccc(-c2nccc3cccc(-c4nccc5ccccc45)c23)cc1</smiles>

six-membered aromatic (QUINAP)



five-membered heteroaromatic configurationally unstable

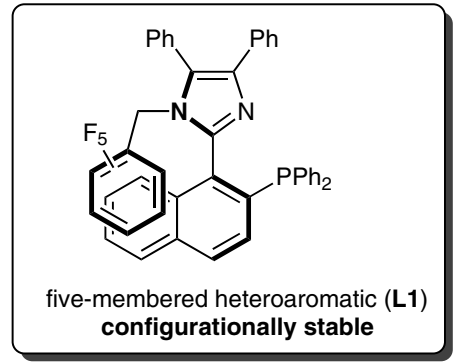

Synthesis of L1:<smiles>CC(C)NC(=O)OCC(=O)OCc1ccc2ccccc2c1C=O</smiles><smiles>Oc1ccc2ccccc2c1-c1nc(-c2ccccc2)c(-c2ccccc2)[nH]1</smiles>

1. $\mathrm{TBSCl} \mathrm{Et}_{3} \mathrm{~N}$ 2. $\mathrm{NaH}, \mathrm{THF}$ $\mathrm{C}_{6} \mathrm{~F}_{5} \mathrm{CH}_{2} \mathrm{Br}$ $-78{ }^{\circ} \mathrm{C}, 94 \%$<smiles>CCOc1ccc2ccccc2c1-c1nc(-c2ccccc2)c(-c2ccccc2)n1CC1CCCCC1</smiles>

1. $\mathrm{K}_{2} \mathrm{CO}_{3}, \mathrm{MeOH}$

2. $\mathrm{PhN}\left(\mathrm{SO}_{2} \mathrm{CF}_{3}\right)_{2}, \mathrm{Et}_{3} \mathrm{~N}$ $\mathrm{CH}_{2} \mathrm{Cl}_{2}, 95 \%$ (2 steps)

3. $\mathrm{Ni}\left(\mathrm{PPh}_{3}\right)_{2} \mathrm{Cl}_{2}, \mathrm{ClPPh}_{2}$ $\mathrm{Zn}, \mathrm{DMF}, 110^{\circ} \mathrm{C}, 60 \%$<smiles></smiles>

rac-L1



$81 \%$

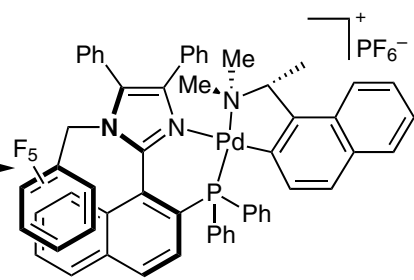
dppe, $\mathrm{CH}_{2} \mathrm{Cl}_{2}$ -78 to $0^{\circ} \mathrm{C}, 1 \mathrm{~h}$ $97 \%$

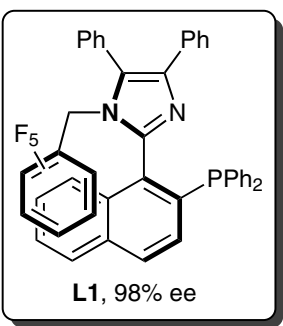

Importance of $\pi$-stacking:<smiles>[Y4]c1ccc2ccc(-c3ccccc3)c(-c3nc(-c4ccccc4)c(-c4ccccc4)n3Cc3ccccc3)c2c1</smiles>

L1 $(\mathrm{X}=\mathrm{F})$ half-life: $8.7 \mathrm{~h}$ at $75^{\circ} \mathrm{C}$ in DCE L1- $\mathrm{H}_{\mathbf{5}}(\mathrm{X}=\mathrm{H})$ half-life: $22 \mathrm{~min}$

Selected example:

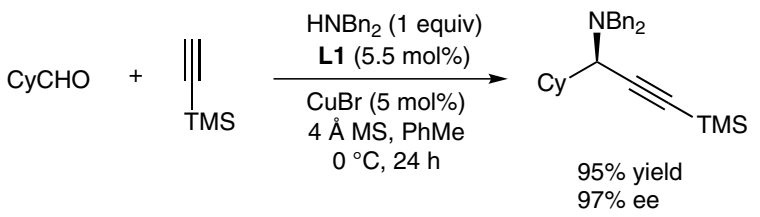

\section{Category}

Metal-Catalyzed

Asymmetric

Synthesis and

Stereoselective

Reactions

\section{Key words}

chiral biaryl

$\mathbf{P}, \mathbf{N}$-ligands

asymmetric alkynylation

copper

Significance: The authors reported the preparation of a new chiral biaryl $\mathrm{P}, \mathrm{N}$-ligand incorporating a five-membered electron-rich heteroaromatic. This ligand is easy to prepare and an effective catalyst for the enantioselective alkynylation of imines.

SYNFACTS Contributors: Hisashi Yamamoto, Masahiro Sa Synfacts 2014, 10(1), 0041 Published online: 13.12.2013 Dol: 10.1055/s-0033-1340430; Reg-No.: H15113SF
Comment: In contrast to the six-membered P,Nligands, five-membered $\mathrm{P}, \mathrm{N}$-ligands are configurationally unstable. The authors have succeeded in preparing a configurationally stable five-membered $\mathrm{P}, \mathrm{N}$-ligand involving $\pi$-stacking interaction, which would offer a new, unexplored chemical diversity. 


\section{Gategory}

Metal-Catalyzed Asymmetric Synthesis and Stereoselective Reactions

\section{Key words}

copper

dialkylzinc

conjugate addition
M. MAGREZ-Chiquet, M. S. T. MORIN, J. WENCEL-DELORD, S. D. AMRAOUi, O. BASLÉ, A. ALEXAKIS, C. CRÉVISY,* M. MAUDUIT* (ECOLE NATIONALE SUPÉRIEURE DE CHIMIE DE RENNES, FRANCE AND UNIVERSITÉ DE GENÈVE, SWITZERLAND)

Enantioselective 1,6-Conjugate Addition of Dialkylzinc Reagents to Acyclic Dienones Catalyzed by Cu-DiPPAM Complex-Extension to Asymmetric Sequential 1,6/1,4-Conjugate Addition

Chem. Eur. J. 2013, 19, 13663-13667.

\section{Cu-Catalyzed Asymmetric 1,6-Conjugate Addition of Dialkylzinc}

Selected examples:
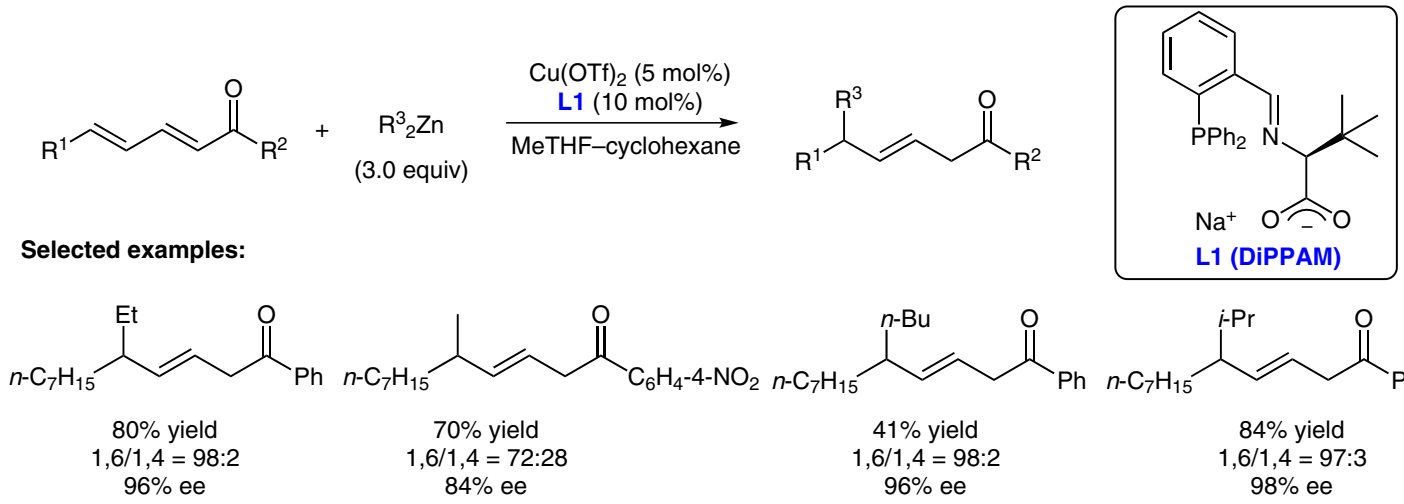<smiles>CCCC=CC(CCCC)C(=O)c1ccccc1</smiles>

Isomerization and 1,4-conjugate addition of 1,6-adducts:<smiles>[R]C(=O)CC=CC([R7])CC</smiles>

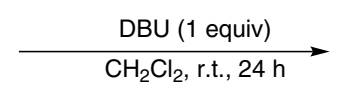<smiles>[R]C(=O)/C=C/CC([R7])CC</smiles>

$\mathrm{R}^{1}=n-\mathrm{C}_{7} \mathrm{H}_{15}, \mathrm{R}^{2}=\mathrm{Ph}: 55 \%$ yield<smiles>[R]C(=O)/C=C/CC([R7])CC</smiles>

L2 (5 mol\%)

CuTC (5 mol\%)

MeTHF-cyclohexane $-40^{\circ} \mathrm{C}, 15 \mathrm{~h}$ $\mathrm{R}^{1}=\mathrm{Me}, \mathrm{R}^{2}=4-\mathrm{ClC}_{6} \mathrm{H}_{4}: 52 \%$ yield

Plausible reaction mechanism:

$\mathrm{R}^{1}=n-\mathrm{C}_{7} \mathrm{H}_{15}, \mathrm{R}^{2}=\mathrm{Ph}: 55 \%$ yield, $>97 \%$ de<smiles></smiles><smiles>[R7]C=CC=CC([R])=O</smiles><smiles>CC[Si](I)(I)I</smiles>

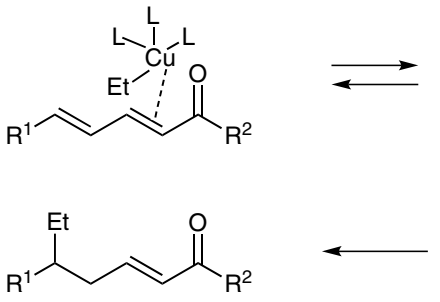

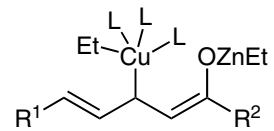<smiles>[B]C(C)(C)/C=C/C=C\OCC</smiles>

Significance: The authors reported the asymmetric 1,6-conjugate addition of dialkylzinc to acyclic dienones catalyzed by copper/phosphinoazomethinylate salt (DiPPAM). After the isomerization of the conjugate adducts, stereoselective sequential 1,4-conjugate addition of diethylzinc was also demonstrated.
Comment: The control of regioselectivity of the 1,6-conjugate addition is difficult due to many parameters. Using copper and the DiPPAM ligand, a highly enantio- and regioselective 1,6-conjugate addition was achieved. With the BINAP ligand, unprecedented highly stereoselective induction is noteworthy.

SYNFACTS Contributors: Hisashi Yamamoto, Yasushi Shimoda

Synfacts 2014, 10(1), 0042 Published online: 13.12.2013 Dol: 10.1055/s-0033-1340436; Reg-No.: H15713SF 


\section{Arylation of Racemic Secondary Benzylic Electrophiles by Nickel Catalysis}

Metal-Catalyzed

Asymmetric

Synthesis and

Stereoselective

Reactions

\section{Key words}

nickel

Negishi crosscoupling

enantioconvergency

1,1-diarylalkanes<smiles>[R]C(O)[Al]</smiles>

$( \pm)-1$
1. $\mathrm{MsCl}, \mathrm{Et}_{3} \mathrm{~N}$

2. $\mathrm{Ar}^{2} \mathrm{Znl}$ (1.7 equiv), $\mathrm{NiBr}_{2}$.diglyme (9 mol\%) $(S, S)-\mathrm{L}$ (13 mol\%), Lil (4 equiv)

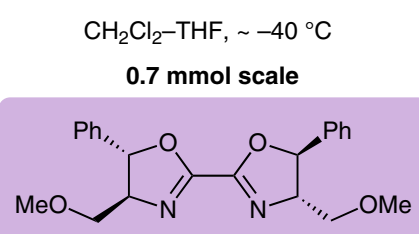

$(S, S)-\mathbf{L}$<smiles>[2H]C([Mg])[AlH2]</smiles>

44 examples up to $96 \%$ yield up to $95 \%$ ee
Selected examples:<smiles>CCC(c1ccccc1)c1ccc(OC)cc1</smiles>

$92 \%$ yield $94 \%$ ee<smiles>CC[C@H](c1ccc(OC)cc1)c1ccc(C(F)(F)F)cc1</smiles>

$94 \%$ ee<smiles>CCC(c1ccc(F)cc1)c1ccc(OC)cc1</smiles><smiles>CCC(c1ccc(OC)cc1)c1ccc2c(c1)OCO2</smiles><smiles>COc1ccc(C(C)c2cccc(N(C)O)c2)cc1</smiles>

$88 \%$ yield $92 \%$ ee<smiles>CC[C@H](c1ccc(OC)cc1)c1ccc2c(ccn2C(=O)OCc2ccccc2)c1</smiles><smiles>CCCCC(c1ccc(OC)cc1)c1ccoc1</smiles>

$88 \%$ yield $93 \%$ ee<smiles>CC(C)(C)OC(=O)CC[C@H](c1ccccc1)c1ccc(Cl)c(Cl)c1</smiles>

using $(R, R)-\mathbf{L}$
Significance: The 1,1-diarylalkane motif is found in a number of the top-selling pharmaceuticals. Therefore, the development of stereoselective methods to access this motif is a worthwhile pursuit. The authors report a two-step stereoconvergent synthesis of 1,1-diarylalkanes starting from racemic benzylic alcohols, which proceeds in excellent yields and with excellent enantioselectivities.

SYNFACTS Contributors: Mark Lautens, Christine M. Le Synfacts 2014, 10(1), 0043 Published online: 13.12.2013 Dol: 10.1055/s-0033-1340452; Reg-No.: L16213SF
Comment: A previous report by the same group disclosed a nickel-catalyzed enantioconvergent Negishi arylation of propargylic carbonates that was not applicable to the use of racemic benzylic carbonates (J. Am. Chem. Soc. 2012, 134, 2966). The current method generates a benzylic mesylate in situ. The authors propose that the lithium iodide additive transforms the mesylate into an alkyl iodide, which can then participate in the Negishi cross-coupling. 


\section{Category}

Metal-Catalyzed Asymmetric Synthesis and Stereoselective Reactions

\section{Key words}

asymmetric alkylation

p-keto esters copper

P. TRILlO, A. BAEZA, * C. NÁJERA* (UNIVERSidAd DE ALiCANTE, SPAIN) Copper-Catalyzed Asymmetric Alkylation of $\beta$-Keto Esters with Xanthydrols Adv. Synth. Catal. 2013, 355, 2815-2821.

\section{Enantioselective Alkylation of $\beta$-Keto Esters}<smiles>[X]c1ccccc1C(O)c1ccccc1[X]</smiles>

Selected examples:<smiles>[X]c1ccccc1C(c1ccccc1[X])C(C(=O)OCC)C(=O)c1ccccc1</smiles>

$\mathrm{X}=\mathrm{O},-50^{\circ} \mathrm{C}$

$82 \%$ yield, $80 \%$ ee

$\mathrm{X}=\mathrm{S}, 0^{\circ} \mathrm{C}$

$45 \%$ yield, $>99 \%$ ee<smiles>[X]c1ccccc1C(c1ccccc1[X])C1(COCC)CCCCC1=O</smiles>

$\mathrm{X}=\mathrm{O},-50^{\circ} \mathrm{C}$

$90 \%$ yield, $16 \%$ ee $\mathrm{X}=\mathrm{S}, 0^{\circ} \mathrm{C}$

$42 \%$ yield, $34 \%$ ee<smiles>O=C1[CH]CCCC1O</smiles>

$\mathrm{Cu}(\mathrm{OTf})_{2}(10 \mathrm{~mol} \%)$ $\underset{\mathrm{PhMe}, \text { Temp, } 20 \mathrm{~h}}{\stackrel{\mathrm{Bu}-\mathrm{BOX}(12 \mathrm{~mol} \%)}{\longrightarrow}}$<smiles>[R]OC(=O)C([R])(C([R])=O)C(c1ccccc1[X])c1ccccc1[X]</smiles><smiles>[R16]OC(C)(C)C(C)(C)[C@@H]1COC(C(C)(C)C2=N[C@H](C(C)(C)C)CO2)=N1</smiles><smiles></smiles>

$\mathrm{X}=\mathrm{O},-50^{\circ} \mathrm{C}$ $89 \%$ yield, $82 \%$ ee $\mathrm{X}=\mathrm{S}, 0^{\circ} \mathrm{C}$ $71 \%$ yield, $63 \%$ ee $\mathrm{X}=\mathrm{S},-20^{\circ} \mathrm{C}$ $75 \%$ yield, $69 \%$ ee $87 \%$ yield, $73 \%$ $\mathrm{X}=\mathrm{S},-20^{\circ} \mathrm{C}$ $37 \%$ yield, $90 \%$ ee<smiles>CCOC(=O)C(C(=O)c1ccccc1)C1C=CC=CC=C1</smiles>

$92 \%$ yield, $30 \%$ ee<smiles>CC(=O)[C@H](C(=O)c1ccccc1)C1c2ccccc2Sc2ccccc21</smiles>

$37 \%$ yield, $85 \%$ ee

Proposed reaction mechanism<smiles>[R]C(=O)CC(C)C</smiles><smiles>[R]C(=O)C(C([R])=O)C(c1ccccc1[X])c1ccccc1CC</smiles>

Significance: The $\mathrm{Cu}(\mathrm{OTf})_{2}$ /tert-butyl-bis-oxazoline catalyst system allows the asymmetric alkylation of $\beta$-keto esters with free benzylic alcohols, for example, xanthydrols as alkylating agents. The reaction is environmentally benign as it generates only water as by-product.
Comment: The reaction between the asymmetric $\mathrm{Cu}(\mathrm{II})-\beta$-keto ester derivative and the in situ generated carbocation proceeds via an $\mathrm{S}_{\mathrm{N}} 1$ mechanism. Albeit unknown, the water produced has a specific role to facilitate the reaction. 


\section{$\mathrm{Rh}_{2}(R-\mathrm{TPCP})_{4}$-Catalyzed Enantioselective Syntheses of 2,5-Dihydroisoxazoles}

Metal-Catalyzed

Asymmetric

Synthesis and

Stereoselective

Reactions

\section{Key words}

[3+2] cycloaddition

nitrones
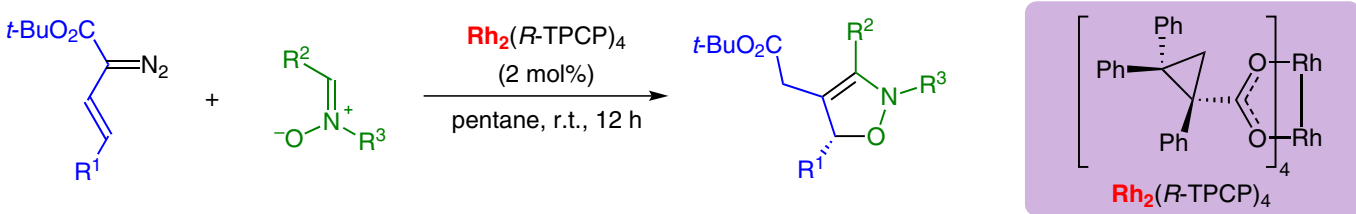

Selected examples:

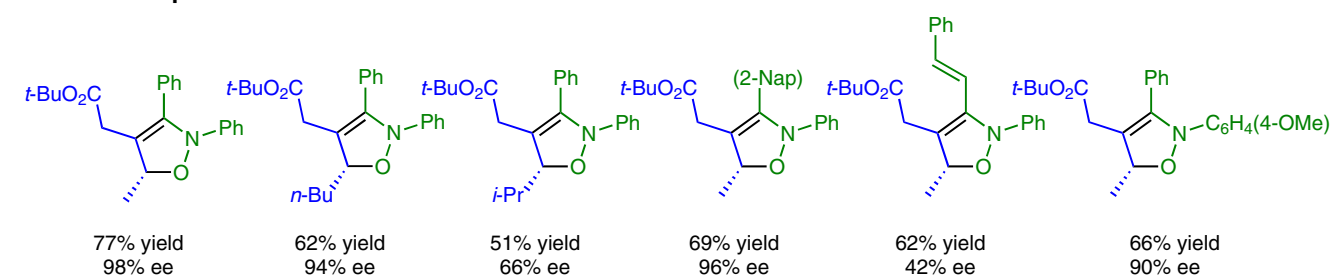

Proposed catalytic cycle:

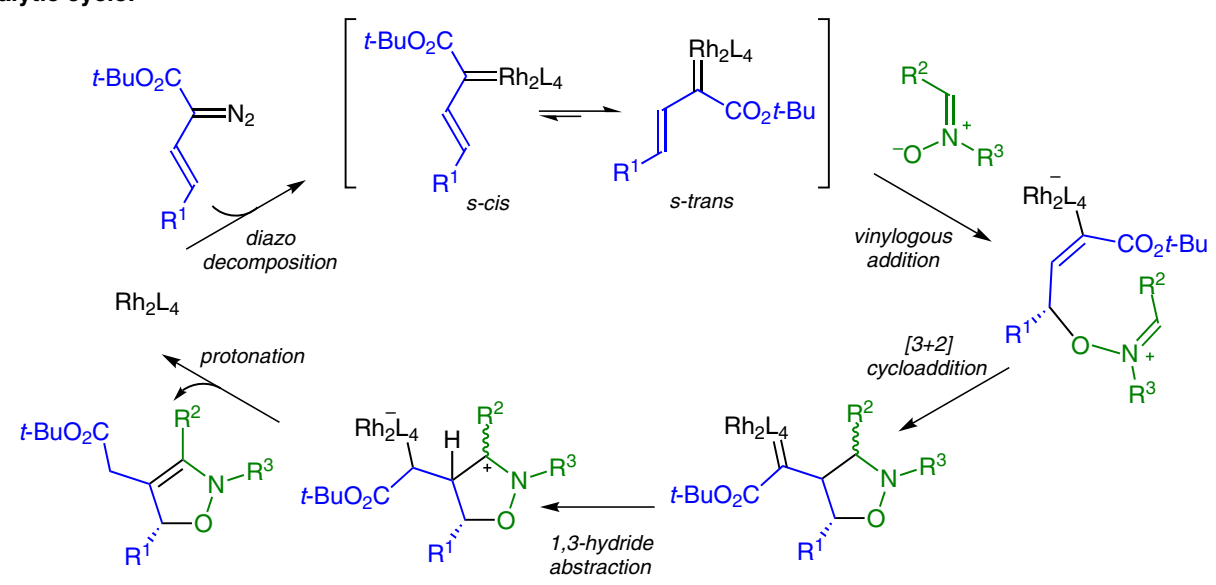

Significance: Exploring the vinylogous reactivity of vinyl rhodium carbenoids, the authors report the $\mathrm{Rh}_{2}(R \text {-TPCP })_{4}$-catalyzed enantioselective formal [3+2] cycloaddition between nitrones and vinyldiazoacetates. With only 2 mol\% of the bulky rhodium catalyst, the 2,5-dihydroisoxazoles were obtained in good yields and moderate to excellent enantioselectivities.
Comment: Doyle and colleagues previously reported a dirhodium complex catalyzed synthesis of 3,6-dihydro-1,2-oxazines via an asymmetric formal [3+3] cycloaddition between nitrones and vinyldiazo compounds (J. Am. Chem. Soc. 2011, $133,16402)$. The highlight of this work is the product divergence from [3+3] to [3+2] cycloaddition leading to 2,5-dihydroisoxazoles with clinical choice of substrate and catalyst. 


\section{Category}

Metal-Catalyzed

Asymmetric

Synthesis and

Stereoselective

Reactions

\section{Key words}

palladium

C-H iodination

desymmetrization

diarylmethylamines
L. CHU, X.-C. WANG, C. E. MOORE, A. L. RHEINGOLD, J.-Q. YU* (THE SCRIPPS RESEARCH INSTITUTE, LA JOLLA AND THE UNIVERSITY OF CALIFORNIA, SAN DIEGO, LA JOLLA,

USA)

Pd-Catalyzed Enantioselective C-H Iodination: Asymmetric Synthesis of Chiral Diarylmethylamines

J. Am. Chem. Soc. 2013, 135, 16344-16347.

\section{Palladium-Catalyzed Enantioselective C-H lodination}
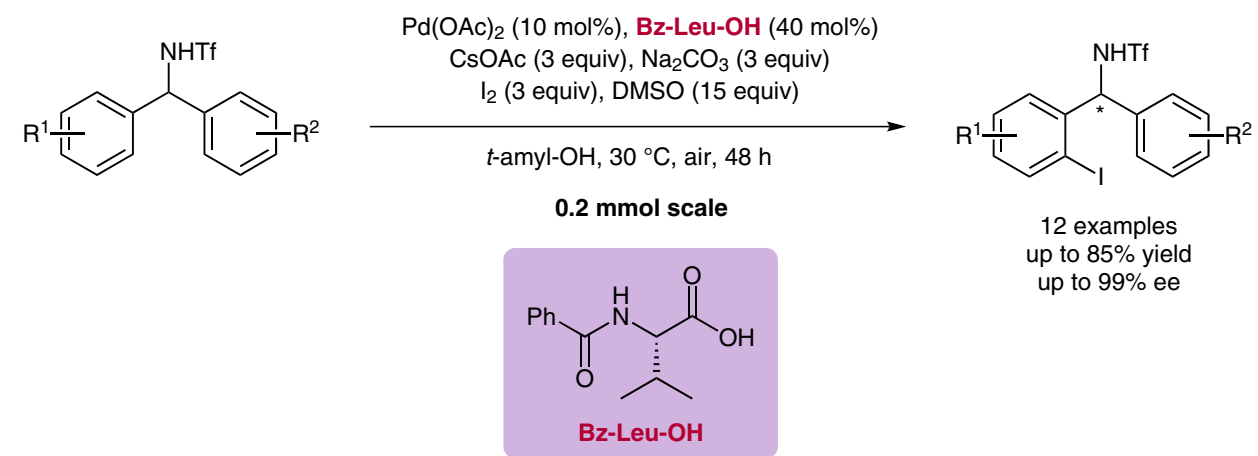

Significance: The diarylmethylamine motif is present in a range of biologically active compounds. Methods aimed at the enantioselective synthesis of diarylmethylamines include 1,2-addition of organometallic species to aldimines (see Review) and asymmetric hydrogenation of the corresponding imines (J. Am. Chem. Soc. 2010, $132,2124)$. Here, the authors report the asymmetric synthesis of diarylmethylamines via palladium-catalyzed desymmetrizing $\mathrm{C}-\mathrm{H}$ iodination. This report is the first example of an asymmetric $\mathrm{C}-\mathrm{H}$ iodination in the absence of a chiral auxiliary.
Comment: The iodination of ortho-substituted substrates proceeds with good yields and excellent enantioselectivities. However, in the absence of ortho substituents, a significant amount of the diiodinated product is obtained. Interestingly, the enantioselectivity of the di-iodinated product remains consistently higher than that of the monoiodinated product.

Review: M. T. Robak, M. A. Herbage, J. A. Ellman Chem. Rev. 2010, 110, 3600-3740. 


\section{Ni-Catalyzed Annulation of Donor-Acceptor Oxiranes with Imines}

\section{Gategory}

Metal-Catalyzed Asymmetric Synthesis and Stereoselective Reactions

\section{Key words}

donor-acceptor oxiranes

cycloaddition

nickel

oxazolidines

\section{Selected examples:}

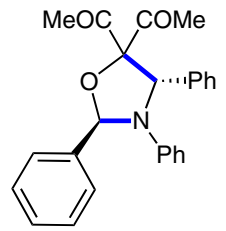

$84 \%$ yield $\mathrm{dr}=18: 1$

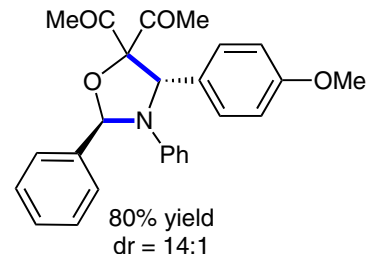

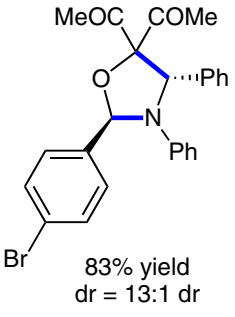

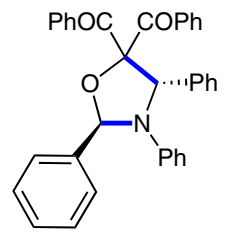

$88 \%$ yield $\mathrm{dr}=16: 1$

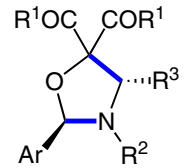

up to $95 \%$ yield dr up to $40: 1$
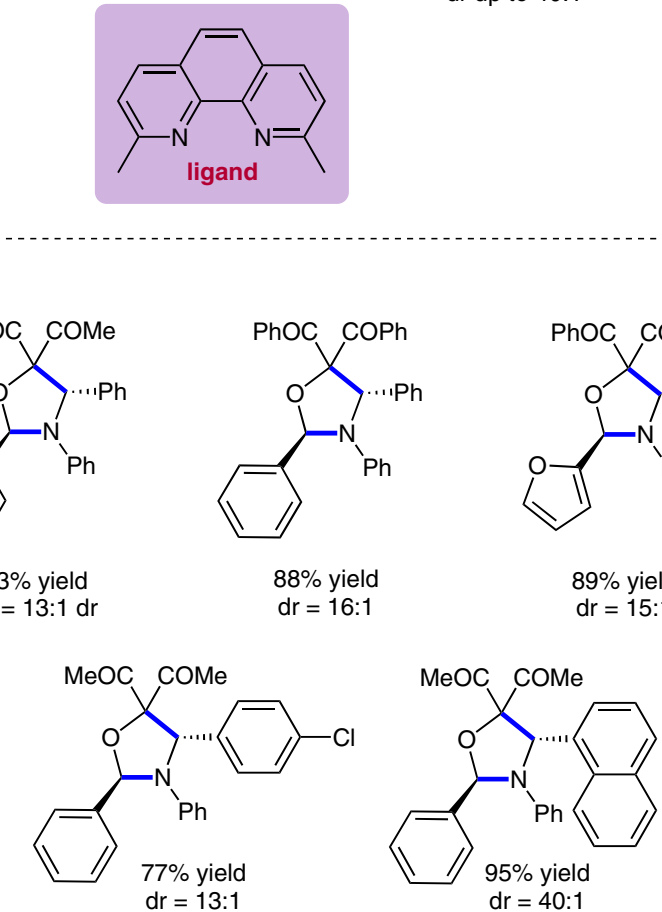

Significance: The use of donor-acceptor oxiranes as 1,3-dipole equivalents in cycloaddition reactions is a useful strategy for the construction of highly substituted heterocycles in a stereoselective fashion. The authors report a diastereoselective synthesis of 2,4-trans-oxazolidines via a nickel-catalyzed [3+2] cycloaddition of donoracceptor oxiranes and imines.
SYNFACTS Contributors: Mark Lautens, Christine M. Le Synfacts 2014, 10(1), 0047 Published online: 13.12.2013 Dol: 10.1055/s-0033-1340450; Reg-No.: L16013SF
Comment: A previous report demonstrated that donor-acceptor aziridines and aldehydes can undergo a [3+2] cycloaddition using a nickel catalyst, which furnishes 2,5-cis-oxazolidines (A. Hennig, A. Hoffmann, H. Borcherding, T. Thiele, U. Schedler, U. Resch-Genger Chem. Commun. 2011, 47, 7842). The current report represents a complementary approach towards oxazolidine scaffolds. The authors demonstrate that two electron-withdrawing groups on the oxirane are required for reactivity, suggesting that chelation to the nickel catalyst is crucial for $\mathrm{C}-\mathrm{C}$ bond cleavage. 


\section{Gategory}

Metal-Catalyzed Asymmetric Synthesis and Stereoselective Reactions

\section{Key words}

\section{copper}

desymmetrization

kinetic resolution

\section{Consecutive Intramolecular}

\section{Desymmetrization and Kinetic Resolution}

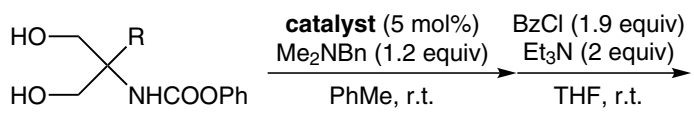<smiles>O=C1NC(P)(COC(=O)c2ccccc2)CO1</smiles>

Selected examples:<smiles>O=C1NC(Cc2ccccc2)(Cc2ccccc2)CO1</smiles><smiles>CCCC1(COC(=O)c2ccccc2)COC(=O)N1</smiles><smiles>C=CC[C@]1(COC(=O)OCc2ccccc2)COC(=O)N1</smiles>

$85 \%$ yield $97 \%$ ee
$74 \%$ yield

$98 \%$ ee<smiles>CCCCOCC[C@@]1(c2ccccc2)COC(=O)N1</smiles>

$87 \%$ yield

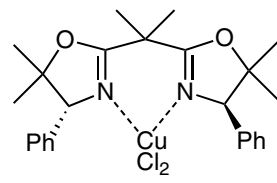

catalyst

Proposed intermediates in desymmetrization and kinetic resolution:

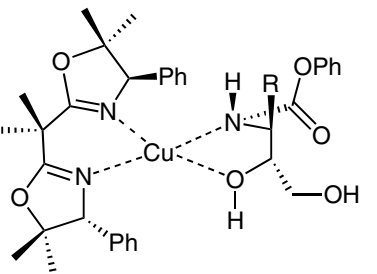
desymmetrization<smiles>O=C1NC(P)(CO)CO1</smiles>

kinetic resolution<smiles>[2H]C[C@]1(COC(=O)c2ccccc2)COC(=O)N1</smiles><smiles>Cc1ccc([C@]2(COC(C)(C)C)COC(=O)N2)cc1</smiles>

$80 \%$ yield
Significance: This paper describes the consecutive intramolecular desymmetrization and kinetic resolution of 2-substituted $\mathrm{N}$-phenoxycarbonylserinols by using bisoxazoline- $\mathrm{CuCl}_{2}$. The reaction products are obtained in good yield and excellent enantioselectivities (94-99\% ee).

SYNFACTS Contributors: Hisashi Yamamoto, Atsuto Izumiseki Synfacts 2014, 10(1), 0048 Published online: 13.12.2013 DOI: 10.1055/s-0033-1340432; Reg-No.: H15313SF
Comment: The authors developed a unique asymmetric catalysis system using a single chiral Lewis acid catalyst, which steers two consecutive asymmetric reactions of intramolecular desymmetrization and kinetic resolution. The two successive chemical conversions became unusually enantioselective, resulting in the production of the oxazolidinone benzoates with excellent enantioselectivities, which signifies a powerful and synergistic dual function catalyst effect by a chiral catalyst. 


\section{Enantioselective Low-Temperature 1,4-Addition of Arylboronic Acids}

\section{Key words}

rhodium

asymmetric 1,4-addition<smiles>O=C1C=CCCC1</smiles>
$\underset{\mathrm{PhMe}-\mathrm{H}_{2} \mathrm{O}(1: 1),-40^{\circ} \mathrm{C}}{\stackrel{(R)-\mathrm{MeO}-\mathrm{F}_{12}-\mathrm{BIPHEP}(0.5 \mathrm{~mol} \%)}{\longrightarrow}}$<smiles>[R]N1C(=O)C=CC1=O</smiles>

$\mathrm{R}=\mathrm{Alk}, \mathrm{Ar}, \mathrm{H}$

Selected examples:<smiles>CN1C(=O)CC(c2ccccc2)C1=O</smiles>

$95 \%$ yield, $92 \%$ ee $\left(-40^{\circ} \mathrm{C}\right)$<smiles>O=C1C[C@H](c2ccccc2)C(=O)N1Cc1ccccc1</smiles>

$95 \%$ yield, $95 \%$ ee $\left(-10^{\circ} \mathrm{C}\right)$<smiles>CN1C(=O)CC(c2ccccc2F)C1=O</smiles>

$99 \%$ yield, $91 \%$ ee $\left(0^{\circ} \mathrm{C}\right)$<smiles>O=C1CC(c2ccccc2)C(=O)N1C1CCCCC1</smiles>

96\% yield, $99 \%$ ee $\left(-10^{\circ} \mathrm{C}\right)$
$[\mathrm{RhOH}(\mathrm{cod})]_{2}(0.25 \mathrm{~mol} \%)$

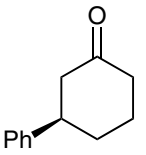

$87 \%$ yield $99.7 \%$ ee )-MeO- $\mathrm{F}_{12}$-BIPHEP (0.5 mol\%)

$\mathrm{Et}_{2} \mathrm{O}-\mathrm{H}_{2} \mathrm{O}(7: 1),<0{ }^{\circ} \mathrm{C}$<smiles>[R]N1C(=O)CC([Al])C1=O</smiles><smiles>COc1cccc([18O])c1-c1c([18O])cccc1[18O]</smiles>

$\mathrm{Ar}^{2}=3,4,5-\mathrm{F}_{3} \mathrm{C}_{6} \mathrm{H}_{2}$ (R)-MeO-F ${ }_{12}$-BIPHEP

arylboronic acids

$\alpha, \beta$-unsaturated carbonyls

low-temperature addition<smiles>COc1ccccc1C1CC(=O)N(C)C1=O</smiles>

$97 \%$ yield, $95 \%$ ee $\left(0^{\circ} \mathrm{C}\right)$<smiles>O=C1CC(c2ccccc2)C(=O)N1c1ccccc1</smiles>

95\% yield, $99 \%$ ee $\left(-10^{\circ} \mathrm{C}\right)$<smiles>CN1C(=O)CC(c2cccc(Cl)c2)C1=O</smiles>

$98 \%$ yield, $92 \%$ ee $\left(0^{\circ} \mathrm{C}\right)$<smiles>O=C1CC(c2ccccc2)C(=O)N1</smiles>

$94 \%$ yield, $87 \%$ ee $\left(-50^{\circ} \mathrm{C}\right)$
Significance: Although various chiral rhodium catalysts have been developed, the rhodiumcatalyzed asymmetric conjugate addition of arylboronic acids to $\alpha, \beta$-unsaturated carbonyl compounds below $0{ }^{\circ} \mathrm{C}$ has not been achieved. This paper describes the rhodium-catalyzed enantioselective 1,4-addition of arylboronic acids at low temperature. The use of the highly electron-poor $(R)-\mathrm{MeO}-\mathrm{F}_{12}$-BIPHEP ligand can retain the activity of the rhodium catalyst, which can serve to improve enantioselectivities.
Comment: A variety of $\mathrm{N}$-substituted maleimides are applicable to this method, affording the corresponding chiral succinimides in excellent yields and enantioselectivities. Notably, the enantioselective 1,4-addition to $\mathrm{N}$-H-maleimide, which has been reported as an inactive substrate for rhodium-catalyzed asymmetric 1,4-addition, is also successful. When the reaction is performed at $-50{ }^{\circ} \mathrm{C}$, the enantioselectivity is improved to up to $87 \%$ ee.

SYNFACTS Contributors: Hisashi Yamamoto, Yusuke Ano 


\section{Gategory}

Metal-Catalyzed Asymmetric Synthesis and Stereoselective Reactions

\section{Key words}

rhodium

diols

phebox ligand
K. TORIBATAKE, H. NISHIYAMA* (NAGOYA UNIVERSITY, JAPAN)

Asymmetric Diboration of Terminal Alkenes with a Rhodium Catalyst and Subsequent Oxidation: Enantioselective Synthesis of Optically Active 1,2-Diols

Angew. Chem. Int. Ed. 2013, 52, 11011-11015.

\section{Rhodium-Catalyzed Enantioselective Synthesis of 1,2-Diols}

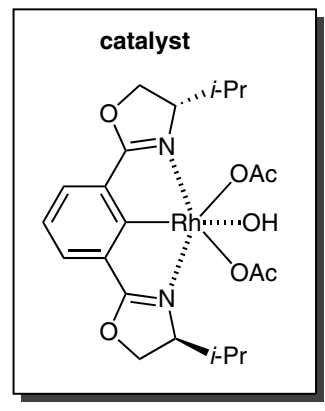

Selected examples:<smiles>OC[C@@H](O)c1ccccc1Cl</smiles>

$96 \%$ yield $99 \%$ ee<smiles>CCc1ccc(C(O)CO)o1</smiles>

$71 \%$ yield<smiles>CC(O)(CO)c1ccccc1</smiles>

$71 \%$ yield<smiles>CCCCCC[C@](C)(O)CO</smiles>

$69 \%$ yield

Proposed catalytic cycle:

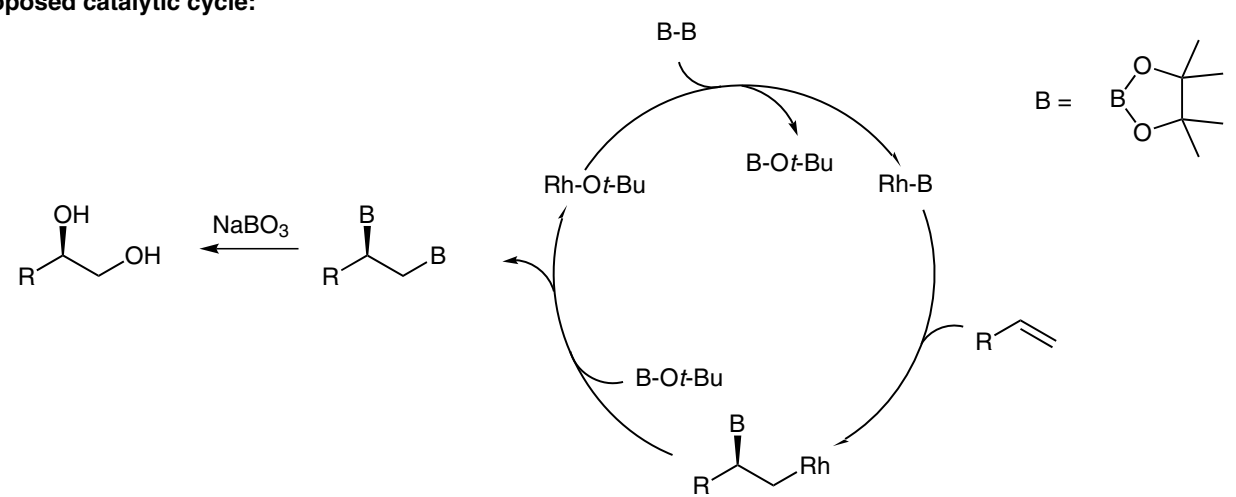

Significance: Chiral diols are useful synthetic motifs in organic synthesis. Common methods for their synthesis include dihydroxylation, hydrogenation of hydroxyketones, and hydrolysis of epoxides. The authors report an enantioselective 1,2diboration of alkenes leading to optically active diols after oxidation.

SYNFACTS Contributors: Mark Lautens, Zafar Quresh Synfacts 2014, 10(1), 0050 Published online: 13.12.2013 DOI: 10.1055/s-0033-1340442; Reg-No.: L15213SF
Comment: Morken showed a similar diboration of terminal alkenes with a platinum catalyst with enantioselectivities up to 94\% (J. Am. Chem. Soc. 2009, 131, 13210). The authors present a rhodium-catalyzed diboration-oxidation of terminal alkenes providing enantioselectivities up to $99 \%$. However, disubstituted alkenes proved to be more difficult. 1-Methylstyrene gave the diol with a moderate $76 \%$ ee, whereas $\beta$-methylstyrene, 1,2-dihydronaphthalene, and trans-stilbene did not react. 


\section{Asymmetric Nickel-Catalyzed Hydrocarbamoylation of Alkenes}<smiles>[R]N(C=O)C([R])([3H])CC=C</smiles>

$\mathrm{Ni}(\operatorname{cod})_{2}(5 \mathrm{~mol} \%), 2$ (5 mol\%) $\mathrm{Ph}_{3} \mathrm{P}(5 \mathrm{~mol} \%), \mathrm{Me}_{3} \mathrm{Al}(40 \mathrm{~mol} \%)$

$\mathrm{PhMe}, 40^{\circ} \mathrm{C}, 12 \mathrm{~h}$

$0.1 \mathrm{mmol}$ scale

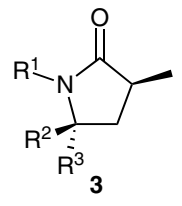

up to $98 \%$ yield dr up to $>20: 1$ er up to $97.5: 2.5$

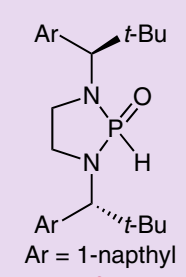

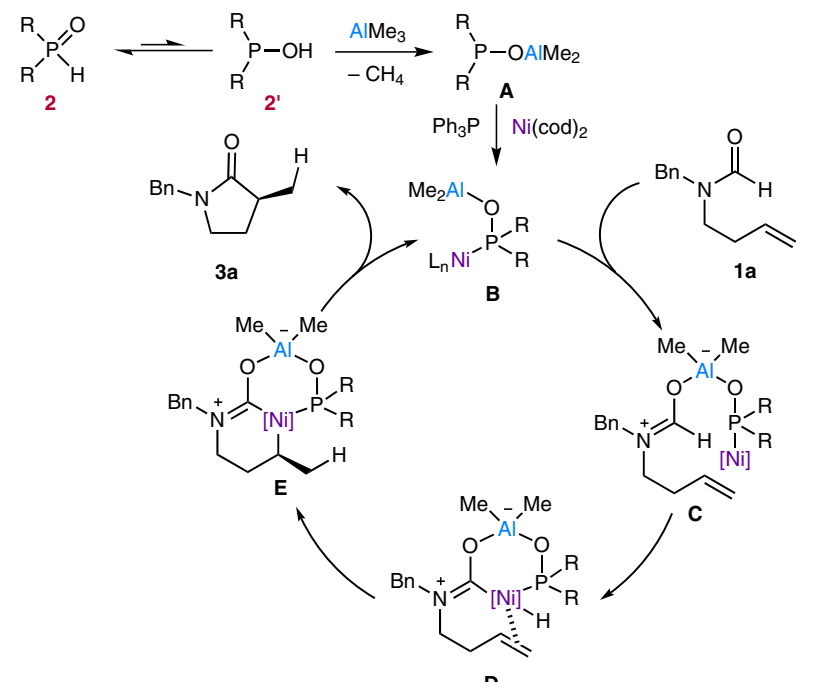

Significance: Secondary phosphine oxides (SPO's) have demonstrated to be versatile and robust preligands in a variety of transition-metal-catalyzed transformations due to their stability to air and moisture (see Review below). The authors report the development of a heterobimetallic catalyst system consisting of aluminum and nickel scaffolded on a chiral SPO tether, which enables the enantioselective intramolecular hydrocarbamoylation of alkenes. This method provides access to enantioenriched pyrrolidones.

Review: N. V. Dubrovina, A. Börner Angew. Chem. Int. Ed. 2004, 43, 5883-5886.

\section{Category}

Metal-Catalyzed Asymmetric

Synthesis and

Stereoselective

Reactions

\section{Key words}

hydrocarbamoy-

lation

phosphine oxide ligands

bimetallic catalysis
Comment: The reaction is believed to initiate via tautomerization of pentavalent phosphine oxide 2 to its trivalent phosphinous acid form, $\mathbf{2}^{\prime}$, which can react with $\mathrm{Me}_{3} \mathrm{Al}$ and form complex A. Coordination to nickel(0) generates the active heterobimetallic catalyst $\mathbf{B}$, which complexes to substrate 1a via the Lewis acidic aluminum center, activating the formyl group towards insertion. Following oxidative addition of nickel into the $\mathrm{C}-\mathrm{H}$ bond, migratory insertion of the pendent olefin and reductive elimination regenerate the catalyst and furnish pyrrolidone $\mathbf{3 a}$. 


\section{Category}

Metal-Catalyzed Asymmetric Synthesis and Stereoselective Reactions

\section{Key words}

rhodium

dynamic kinetic asymmetric transformation

allenes
D. N. TRAN, N. CRAMER* (ÉCOLE POLYTECHNIQUE FÉDÉRALE DE LAUSANNE, SWITZERLAND)

Rhodium-Catalyzed Dynamic Kinetic Asymmetric Transformations of Racemic Allenes by the [3+2] Annulation of Aryl Ketimines

Angew. Chem. Int. Ed. 2013, 52, 10630-10634.

\section{Enantioselective Rhodium-Catalyzed DYKAT of Racemic Allenes}<smiles>[R]C=C([18F])C[R7]</smiles>
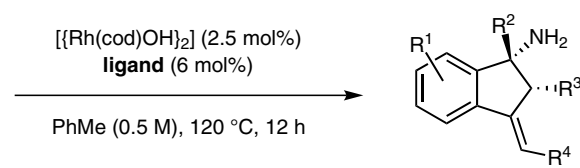

up to $97 \%$ yield er up to $99: 1$ E/Z up to $>20: 1$
$(0.1 \mathrm{mmol}$ scale $)$

Selected examples:<smiles>CCC=C1c2ccccc2[C@@](N)(c2ccccc2)C1CCC</smiles><smiles>C[C@]1(N)c2ccncc2/C(=C/Br)C1c1ccccc1</smiles>
21 examples

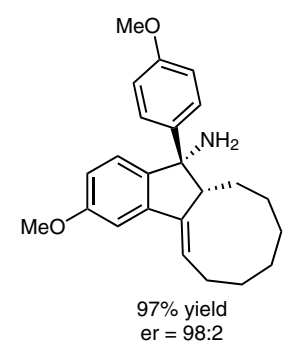<smiles>C[C@]1(N)c2ccccc2/C(=C/Br)[C@@H]1c1ccco1</smiles>

$96 \%$ yield $E / Z=13: 1$ Proposed catalytic cycle:

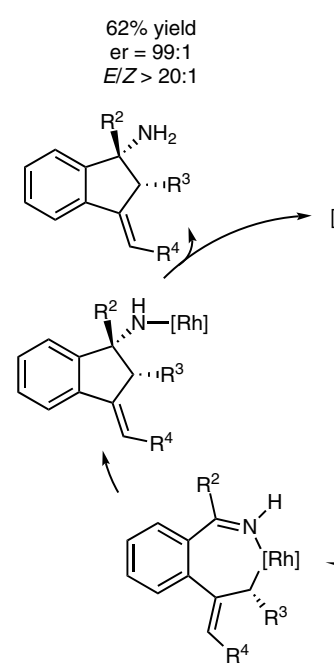

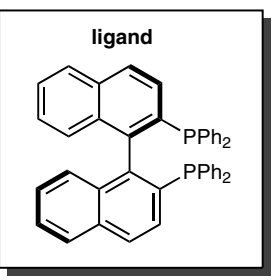

$\left[\mathrm{L} \cdot \mathrm{Rh}^{\prime}\right]$<smiles>[R]C(=N)c1ccccc1CC(C)C</smiles><smiles>[R]C1=N[In]c2ccccc21</smiles>

$\overrightarrow{\text { DYKAT }}$

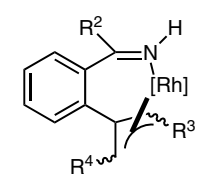

Significance: Chiral amines are present in numerous biologically active compounds (see Book below). Starting from readily accessible racemic allenes, the authors were able to access indane structures containing chiral amines via a dynamic kinetic asymmetric transformation (DYKAT) in a [3+2] cycloaddition.

Book: Chiral Amine Synthesis: T. C. Nugent, Ed.; Wiley-VCH: Weinheim, 2010.
Comment: The rhodium hydride, formed by the initial directed $\mathrm{C}-\mathrm{H}$ activation, adds across the racemic allene forming a rhodium allyl species. The rhodium allyl species can then interconvert via $\sigma-\pi-\sigma$ isomerization leading to a chiral intermediate which adds to the imine (see below for a Review on axis-to-center chirality transfer).

Review: N. Krause, C. Winter Chem. Rev. 2011, 111, 1994-2009. 


\section{Synthesis of Spiro-[Butyrolactone- Pyrrolidine]}

\section{Category}

Metal-Catalyzed

Asymmetric

Synthesis and

Stereoselective

Reactions

\section{Key words}

azomethine ylides

copper

spirocycles
Significance: The authors developed an asymmetric synthesis of spiro-[butyrolactone-pyrrolidine] catalyzed by $\mathrm{Cu}(\mathrm{I})$-DTBM-BIPHEP delivering exo-selective 1,3-dipolar cycloadducts of azomethine ylides and $\alpha$-methylene- $\gamma$-butyrolactone. In all cases excellent chemical yields and stereoselectivities were achieved.
Comment: Several natural alkaloids and important biological compounds contain spiro-[butyrolactone-pyrrolidine] as core structure making them very attractive targets in the synthetic community. Thus, this finding for the syntheses of bicyclic and tricyclic skeletons with multiple quaternary stereogenic centers is very attractive. 


\section{Category}

Metal-Catalyzed Asymmetric Synthesis and Stereoselective Reactions

\section{Key words}

$\alpha, \beta$-unsaturated $\gamma$-keto esters $\gamma$-butenolides $N, N^{\prime}$-dioxides

Michael addition scandium
J. JI, L. LIN, L. ZHOU, Y. ZHANG, Y. LIU, X. LIU, X. FENG* (SICHUAN UNIVERSITY, CHENGDU, P. R. OF CHINA)

$N, N^{\prime}$-Dioxide-Scandium(III)-Catalyzed Asymmetric Michael Addition of $\beta, \gamma$-Unsaturated Butenolides to $\alpha, \beta$-Unsaturated $\gamma$-Keto Esters

Adv. Synth. Catal. 2013, 355, 2764-2768.

\section{$N, N^{\prime}$-Dioxide-Scandium(III)-Catalyzed Asymmetric Michael Addition}

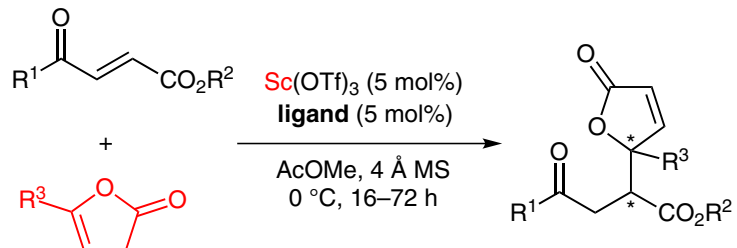

Selected examples:<smiles>CCOC(=O)C(CC(=O)c1ccccc1)C1(C)C=CC(=O)O1</smiles>

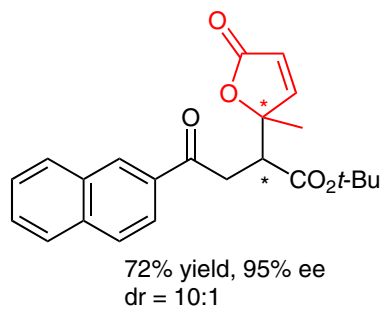
$\mathrm{dr}=10: 1$

Proposed transition state:

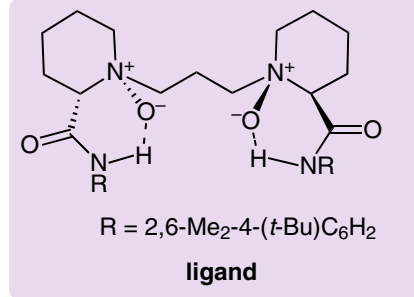

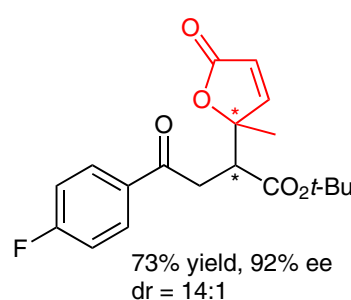<smiles>CCC1(C(CC(=O)c2ccccc2)C(=O)OC(C)(C)C)C=CC(=O)O1</smiles>

$50 \%$ yield, $97 \%$ ee $\mathrm{dr}>19: 1$
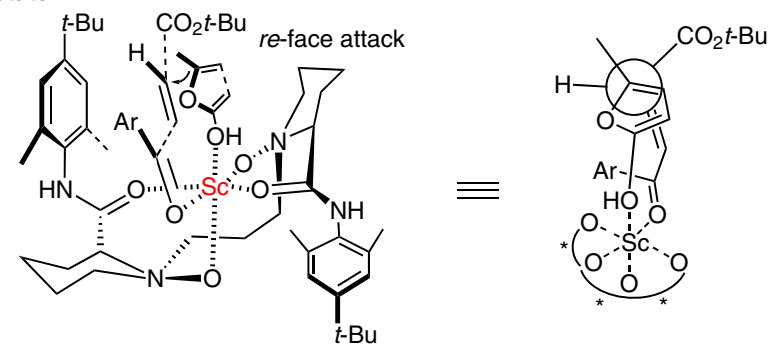

Significance: Butenolide derivatives represent an important structural motif in natural products and pharmaceuticals. The authors develop a highly efficient catalytic system for the asymmetric vinylogous Michael addition of $\gamma$-substituted butenolides to $\alpha, \beta$-unsaturated $\gamma$-keto esters, leading to $\gamma, \gamma$-disubstituted butenolides in good yield and excellent enantioselectivities.

SYNFACTS Contributors: Hisashi Yamamoto, Fengtao Zhou Synfacts 2014, 10(1), 0054 Published online: 13.12.2013 Dol: 10.1055/s-0033-1340455; Reg-No.: H16213SF
Comment: The substrate scope of this reaction is well investigated. The ester groups of the $\alpha, \beta$-unsaturated $\gamma$-keto esters display an influence on both diastereo- and enantioselectivity. The bulkier $\gamma$-substituted groups in the butenolides lead to the increase of diastereo- and enantioselectivity, but the reactivities decrease obviously. Aromatic and aliphatic unsaturated $\gamma$-keto esters are well tolerated. 


\section{Enantioselective Homologation of $\alpha$-Keto Esters with $\alpha$-Diazo Esters}

\section{Key words}

diazo esters

$\alpha$-keto esters

yttrium

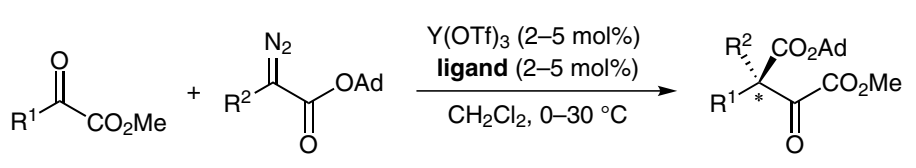

$\mathrm{Ad}=1$-adamantyl<smiles>COC(=O)C(C)(OC(C)=O)c1ccccc1</smiles>

$73 \%$ yield, $92 \%$ ee<smiles>C=CCC(C(=O)OC)(C(=O)OC)c1cccc(C)c1</smiles>

$55 \%$ yield, $86 \%$ ee<smiles>CC(=O)OC(C)=O</smiles>

$73 \%$ yield, $95 \%$ ee<smiles>C#CCC(C(C)=O)(C(=O)OC)c1cccc(C)c1</smiles>

$65 \%$ yield, $91 \%$ ee<smiles>COC(=O)[C@@](C)(c1cccc(Cl)c1)C(C)(C)OC(C)=O</smiles>

$70 \%$ yield, $93 \%$ ee<smiles>COC(=O)C(C)(CCCCCl)C(=O)OC</smiles>

$76 \%$ yield, $94 \%$ ee

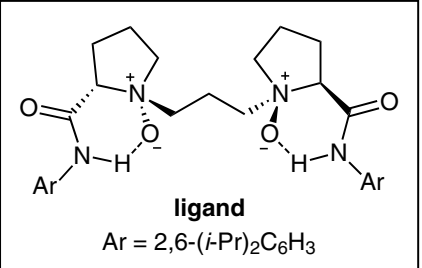<smiles>CC(=O)OC(=O)C(C)(C(C)=O)c1ccc(/C=C/c2ccccc2)cc1</smiles>

$71 \%$ yield, $92 \%$ ee<smiles>CC(=O)OC(=O)C(C)(C)OC(C)=O</smiles>

$70 \%$ yield, $94 \%$ ee

Proposed stereochemical model:
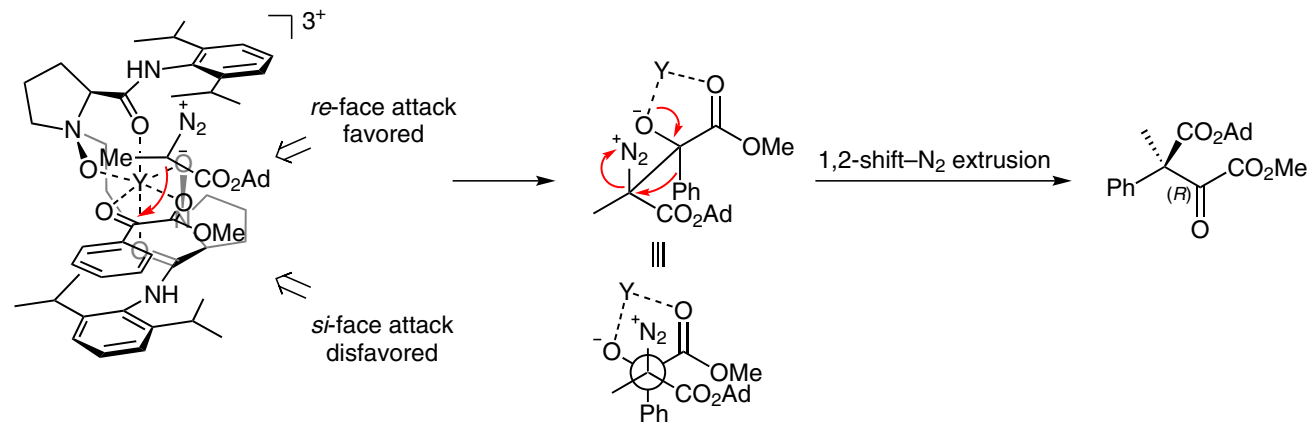
disfavored

Significance: The Lewis acid catalyzed homologation of carbonyl compounds with diazo compounds can realize synthetically useful carbon chain extension. The authors achieve the asymmetric homologation of acyclic $\alpha$-keto esters with $\alpha$-diazo esters by using chiral $N, N^{\prime}$-dioxide-yttrium(III) complexes. Both aryl- and alkyl-substituted $\alpha$-keto esters are applicable, providing the corresponding succinate derivatives in good yields and enantioselectivities.

SYNFACTS Contributors: Hisashi Yamamoto, Yusuke Ano Synfacts 2014, 10(1), 0055 Published online: 13.12.2013 Dol: 10.1055/s-0033-1340454; Reg-No.: H16113SF
Comment: The use of bulky adamantyl $\alpha$-diazo esters can suppress the formation of undesired by-products. Steric hindrance on the 2,6-positions of the phenyl ring in the ligand is also essential to improve both enantioselectivity and reactivity. The attack of $\alpha$-diazo ester occurs from re-face of the coordinating $\alpha$-keto ester preferably due to the obstruction of si-face by the aryl group in the $N, N^{\prime}$-dioxide ligand. 


\section{Gategory}

Metal-Catalyzed Asymmetric Synthesis and Stereoselective Reactions

\section{Key words}

\section{silver}

monophosphines

vinylogous Mannich reaction

L.-S. ZHENG, L. LI, K.-F. YANG, Z.-J. ZHENG, X.-Q. XIAO, L.-W. XU* (HANGZHOU NORMAL UNIVERSITY AND LANZHOU INSTITUTE OF CHEMICAL PHYSICS, P. R. OF CHINA)

New Silver(I)-Monophosphine Complex Derived from Chiral Ar-BINMOL: Synthesis and Catalytic Activity in Asymmetric Vinylogous Mannich Reaction Tetrahedron 2013, 69, 8777-8784.

\section{Silver(I)-Monophosphine-Catalyzed Asymmetric Mannich Reaction}



Selected examples:<smiles>O=C1C=C[C@@H]([C@H](Nc2ccccc2)c2ccccc2)O1</smiles><smiles>CC(C)(C)[13CH2][13CH3]</smiles>
$\mathrm{dr}>99: 1$<smiles>O=C1C=CC(C(Nc2ccccc2)c2ccccc2)O1</smiles><smiles>CCOc1ccc(N[C@H](c2ccccc2)[C@H]2C=CC(=O)O2)cc1</smiles><smiles>O=C1C=CC(C(Nc2ccccc2)C2CCCCC2)O1</smiles>

$50 \%$ yield, $30 \%$ ee $\mathrm{dr}=94: 6$<smiles>P=C(c1cccc2ccccc12)c1c(Br)ccc2ccccc12</smiles>

ligand
Significance: The authors developed a new class of axially chiral monophosphine ligands for silvercatalyzed asymmetric reactions. This catalytic system shows good catalytic activities and good enantioselectivities in an asymmetric vinylogous Mannich reaction.

SYNFACTS Contributors: Hisashi Yamamoto, Fengtao Zhou Synfacts 2014, 10(1), 0056 Published online: 13.12.2013 Dol: 10.1055/s-0033-1340456; Reg-No.: H16313SF
Comment: These air-stable ligands can be synthesized easily on gram scale in good yields from available starting materials. The benzyl group of the chiral monophosphine not only offers weak silver- $\pi / \pi-\pi$ stacking, but also provides steric repulsion to favor the diastereoselective re-nucleophilic addition of siloxyfuran to the imine. 


\section{Pd-Catalyzed Asymmetric Ring Opening of Azabenzonorbornadienes}

\section{Gategory}

Metal-Catalyzed

Asymmetric

Synthesis and

Stereoselective

Reactions

\section{Key words}

asymmetric ring opening

azabenzonorbornadienes

chiral spiro ligands

palladium<smiles>CC(C)(C)OC(=O)C1C=Cc2ccccc2C1NC(=O)c1cccc(F)c1</smiles>

$80 \%$ yield, $85 \%$ ee<smiles>O=C1NC2c3ccccc3C=CC2c2cc(Cl)ccc21</smiles>

$67 \%$ yield, $76 \%$ ee
(MeCN)

$\mathrm{Zn}$ (10 equiv), $\mathrm{I}_{2}\left(1\right.$ equiv), Et ${ }_{3} \mathrm{~N}$ (0.5 equiv)

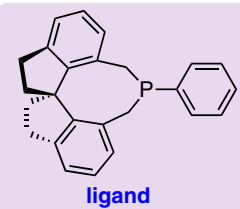<smiles>COc1ccc2c(c1)C(=O)NC1c3ccccc3C=CC21</smiles>

$82 \%$ yield, $81 \%$ ee<smiles>O=C1NC2c3ccccc3C=CC2C2=CC[Te]CC=C12</smiles><smiles>O=C1NC2c3ccccc3C=CC2c2ccc(OC(F)(F)F)cc21</smiles>

$78 \%$ yield, $80 \%$ ee

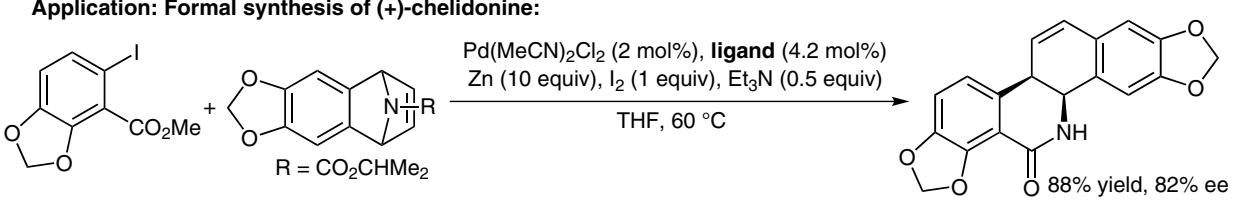

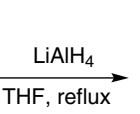<smiles>C1=CC2c3ccc4c(c3CNC2c2cc3c(cc21)OCO3)OCO4</smiles>

$\underset{\mathrm{CH}_{2} \mathrm{Cl}_{2}, \text { r.t. }}{\mathrm{CbzCl}, \mathrm{Et}_{3} \mathrm{~N}}$<smiles>O=[N+]([O-])N1Cc2c(ccc3c2OCO3)C2C=Cc3cc4c(cc3C21)OCO4</smiles><smiles>C#CC=C</smiles><smiles>O=[N+]([O-])N1Cc2c(ccc3c2OCO3)C2C1c1cc3c(cc1C[C@@H]2O)OCO3</smiles>

Significance: In the presence of electron-rich chiral spirophosphine ligands, $\mathrm{I}_{2}$ as key additive, and zinc powder as reducing agent, $\mathrm{Pd}(\mathrm{MeCN})_{2} \mathrm{Cl}_{2}$ efficiently catalyzes the ring opening of azabenzonorbornadiene with various 2-iodobenzoates. The resulting enantioenriched cis-dihydrobenzo[c]phenanthridinones serve as core structure of numerous optically active natural products.
Comment: The use of easily available organic halides instead of organometallic reagents and the construction of fused ring systems with multiple stereocenters via the tandem asymmetric ringopening-cyclization process make the strategy remarkably efficient. A direct application of the present methodology was demonstrated via the concise total synthesis of $(+)$-chelidonine.

SYNFACTS Contributors: Hisashi Yamamoto, Sukalyan Bhadra 


\section{Category}

Metal-Catalyzed Asymmetric Synthesis and Stereoselective Reactions

\section{Key words}

\section{rhodium}

kinetic resolution diamine ligands
M.-K. LEMKE, P. SCHWAB, P. FISCHER, S. TISCHER, M. WITT, L. NOEHRINGER, V. ROGACHEV, A. JÄGER, O. KATAEVA, R. FRÖHLICH, P. METZ* (TECHNISCHE UNIVERSITÄT DRESDEN UND WESTFÄLISCHE WILHELMS-UNIVERSITÄT MÜNSTER, GERMANY; TOMSK POLYTECHNIC UNIVERSITY, RUSSIA)

A Practical Access to Highly Enantiomerically Pure Flavanones by Catalytic Asymmetric Transfer Hydrogenation Angew. Chem. Int. Ed. 2013, 52, 11651-11655.

\section{Rhodium-Catalyzed Asymmetric Transfer Hydrogenation}<smiles>[R17]Oc1ccc(C2CC(=O)c3ccccc3O2)cc1</smiles>

up to $0.373 \mathrm{mmol}$<smiles>O=C1CC(c2ccc(O)cc2)Oc2ccccc21</smiles>

up to $50 \%$ yield up to $>99 \%$ ee

Selected examples:

Significance: Chiral flavanone moieties are among the largest secondary metabolites in plants. As such, they have been known for their antifungal, antibacterial, and antiviral effects. The authors present a practical and convenient method for the synthesis of both enantiomers of this class of molecules.
Comment: The catalytically active rhodium hydride species was generated in situ prior to the addition of the substrate. This method allowed the authors to reduce catalyst loading to $0.5 \mathrm{~mol} \%$ while retaining high enantioselectivities. They were able to synthesize both enantiomers of the natural product glabrol.

SYNFACTS Contributors: Mark Lautens, Zafar Qureshi 


\section{Ring Opening of Azabicyclic Alkenes Co- Catalyzed by Palladium and Copper}

Metal-Catalyzed Asymmetric

Synthesis and Stereoselective Reactions

\section{Key words}

desymmetrization

asymmetric ring opening

\section{palladium}

copper

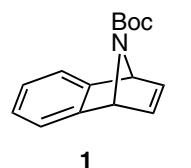

(1.0 equiv)

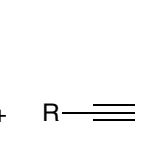

2

(5.0 equiv)
(R)-xyl-BINAP $(6 \mathrm{~mol} \%)$

CuOTf (10 mol\%)

DME, $0^{\circ} \mathrm{C}$

$0.2 \mathrm{mmol} \mathrm{scale}$



up to $98 \%$ yield up to $>99.9 \%$ ee

Proposed mechanism:

$\mathrm{H}^{+}$<smiles>CC(C)(C)OC(=O)N(Cl)C1c2ccccc2C=CC1C#CF</smiles>

$\mathrm{Pd}(\mathrm{OAc})_{2}$

(R)-xyl-BINAP

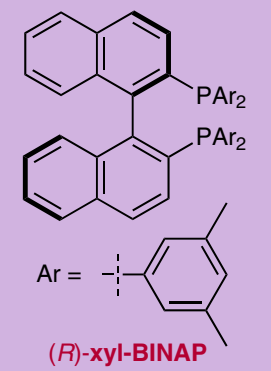

$\mathrm{Boc}^{-}{ }^{-} \mathrm{Cu}$

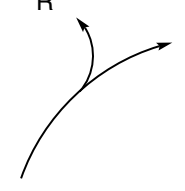

$[\mathrm{Pd}]^{*}$

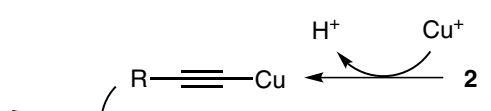

Selected examples:

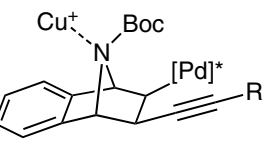

\section{$R$}

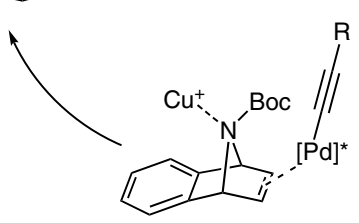

$\mathrm{R}=[\mathrm{Pd}]^{*}$

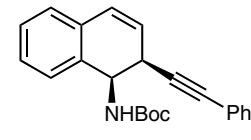

$97 \%$ yield $97 \%$ ee

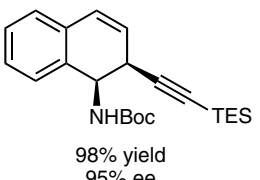

$95 \%$ ee

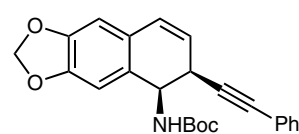

$89 \%$ yield $94 \%$ ee

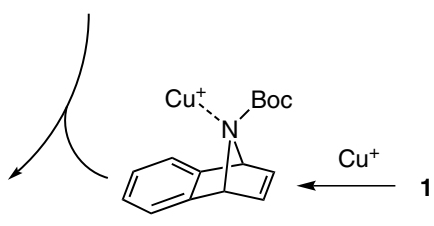

Significance: The ring opening of strained mesoheterobicyclic alkenes with different nucleophiles serves as a useful strategy for setting multiple stereocenters in a single transformation. Previous methods for this particular ring opening were limited to the use of bulky terminal acetylenes. Here, the authors report the development of a palladium and copper co-catalyzed system that exhibits broad substrate scope.
Comment: The authors propose that the copper(I) catalyst plays two distinct roles in the mechanism: (1) Copper facilitates transmetalation of the acetylene to palladium via the copper acetylide; (2) Copper behaves as a Lewis acid to activate the azabicyclic alkene. In addition to demonstrating wide functional group tolerance, the yields and enantioselectivities observed are excellent across the series of substrates tested.

SYNFACTS Contributors: Mark Lautens, Christine M. Le 


\section{Category}

Metal-Catalyzed Asymmetric Synthesis and Stereoselective Reactions

\section{Key words}

\section{iridium}

hydrogenation

alkenyl boronates
S. J. ROSEblade, E. CASAS-ARCÉ, U. NetTeKoven, I. G. SMilović, A. ZANottiGEROSA, Z. ČASAR* (JOHNSON MATTHEY, CAMBRIDGE, UK; SOLVIAS AG, KAISERAUGST, SWITZERLAND; LEK PHARMACEUTICALS, MENGEŠ, SOLVENIA; SANDOZ GMBH, KUNDL, AUSTRIA; UNIVERSITY OF LJUBLJANA, SOLVENIA)

A Practical Synthetic Approach to Chiral ( $\alpha$-Chloroalkyl)boronic Esters via Iridium-Catalyzed Chemoselective Hydrogenation of Chloro-Substituted Alkenyl Boronates

Synthesis 2013, 45, 2824-2831.

\section{Enantioselective Hydrogenation of Chloro- Substituted Alkenyl Boronates}

Significance: Enantioenriched ( $\alpha$-chloroalkyl)boronic esters represent an important class of building blocks frequently used in organic synthesis. These chiral halogenated compounds are most commonly synthesized via Matteson-type rearrangements which use stoichiometric lithiated reagents, leading to stoichiometric waste streams. Transition-metal-catalyzed asymmetric hydrogenation has become the premier method for setting diversely substituted stereocenters with high enantiomeric excess under more environmentally friendly conditions. The authors report the synthesis of enantioenriched ( $\alpha$-chloroalkyl)boronic esters via the iridium-catalyzed asymmetric hydrogenation of chloro-substituted alkenyl boronates. SYNFACTS Contributors: Mark Lautens, David A. Petrone Synfacts 2014, 10(1), $0060 \quad$ Published online: 13.12.2013 Dol: 10.1055/s-0033-1340445; Reg-No.: L15513SF

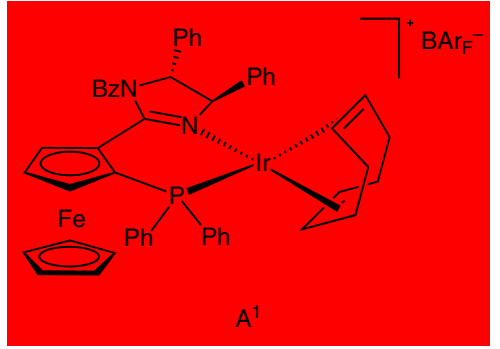<smiles>CC(C)(C)C[C@@H](Cl)[B]c1ccccc1</smiles>

A/B $=90: 10$ $86 \%$ yield $A, 93 \%$ ee<smiles>COc1ccc(C[C@H](Cl)c2ccccc2)cc1</smiles>

A/B $=88: 12$ $73 \%$ yield $\mathbf{A}, 88 \%$ ee

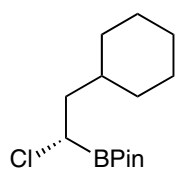

A/B $=95: 5$

$85 \%$ yield $\mathrm{A}, 92 \%$ ee

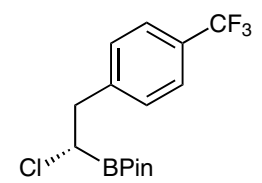

$\mathbf{A} / \mathbf{B}=81: 19$ $65 \%$ yield A, $94 \%$ ee
Comment: The authors present a protocol for the enantioselective iridium-catalyzed hydrogenation of chloro-substituted alkenyl boronates using a ferrocenyl phosphinoimidazoline ligand. Good to excellent yields and enantioselectivities were obtained for both alkyl- and aryl-bearing substrates. Substrate-to-catalyst ratios (S/C) of up to 25 and hydrogen pressures as low as 5 bar are reported. This catalytic system benefits from a low amount of dechlorinated products resulting from overreduction. 


\section{Catalytic Alkenylation of Neopentyl Palladium Species Using $\boldsymbol{N}$-Tosyl Hydrazones}

Metal-Catalyzed Asymmetric

Synthesis and

Stereoselective

Reactions

\section{Key words}

palladium

Heck reaction

N-tosyl hydrazones

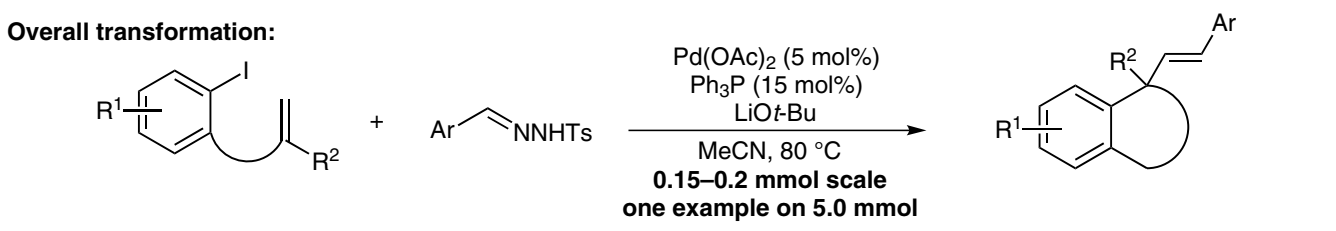<smiles>Cc1ccccc1/C=C/C1(C)C(=O)Nc2ccccc21</smiles>

$99 \%$ yield<smiles>CC1(/C=C/c2ccccc2)C(=O)Nc2ccccc21</smiles>

$99 \%$ yield<smiles>COc1ccccc1/C=C/C1(C)C(=O)Nc2ccccc21</smiles>

$99 \%$ yield<smiles>COc1ccccc1/C=C/C1(c2ccccc2)C(=O)Nc2ccccc21</smiles>

$97 \%$ yield<smiles>CC1(/C=C/c2ccc(Cl)cc2)C(=O)Nc2ccccc21</smiles>

$87 \%$ yield<smiles>CN1CC(/C=C/c2ccccc2)(c2ccccc2)c2ccccc21</smiles>

$65 \%$ yield

\section{Reaction involving a diene substrate:}<smiles>C=C(C)CCC(=C)C(=O)Nc1ccccc1I</smiles>

$\mathrm{Pd}(\mathrm{OAc})_{2}(5 \mathrm{~mol} \%)$ $\mathrm{Ph}_{3} \mathrm{P}(15 \mathrm{~mol} \%)$ LiOt-Bu $\mathrm{MeCN}, 80^{\circ} \mathrm{C}$ $61 \%$ yield, trans $/$ cis $=1.2: 1$
4- $\mathrm{MeOC}_{6} \mathrm{H}_{4}$<smiles>CC1(/C=C/P)CCC2(CC1)C(=O)Nc1ccccc12</smiles><smiles>CC1(/C=C/c2ccc(C#N)cc2)C(=O)Nc2ccccc21</smiles>

$70 \%$ yield<smiles>COc1ccc(/C=C/C2(c3ccccc3)CCc3ccccc32)cc1</smiles>

$97 \%$ yield
Significance: Palladium-catalyzed Heck-type cascades have long been used to install molecular complexity in a single transformation. In early pioneering work, Negishi and Grigg have reported cascade processes involving carbonylation sequences, Stille and Suzuki couplings, as well as $\mathrm{C}-\mathrm{H}$ functionalization as terminating steps. However, despite these advances, terminations involving palladium carbenes have been far less explored. Gu and co-workers report the combination of $N$-tosyl hydrazone derived carbenes and in situ generated alkyl palladiums in a new alkenylation reaction.

SYNFACTS Contributors: Mark Lautens, David A. Petrone Synfacts 2014, 10(1), 0061 Published online: 13.12.2013 Dol: 10.1055/s-0033-1340447; Reg-No.: L15713SF
Comment: The authors present a palladium-catalyzed Heck-type cascade reaction en route to alkene products. By terminating the cyclization sequence with a reaction with $N$-tosyl hydrazones, products can be obtained with high $E / Z$ ratios. The method benefits from the ability to generate diverse hetero- and carbocycles in good to excellent yields under relatively mild conditions, using a simple palladium(II) pre-catalyst. Cyclization onto electron-deficient alkenes was shown to be preferred in a competition experiment involving a diene substrate. 
Metal-Catalyzed Asymmetric Synthesis and Stereoselective Reactions

\section{Key words}

palladium

thioether

polyfluoroarenes
C.-Z. WU, C.-Y. HE, Y. HUANG, X. ZHANG* (DONGHUA UNIVERSITY, SHANGHAI AND SHANGHAI INSTITUTE OF ORGANIC CHEMISTRY, P. R. OF CHINA)

Thioether-Promoted Direct Olefination of Polyfluoroarenes Catalyzed by Palladium Org. Lett. 2013, 15, 5266-5269.

\section{Oxidative Olefination of Polyfluoroarenes Catalyzed by Palladium}

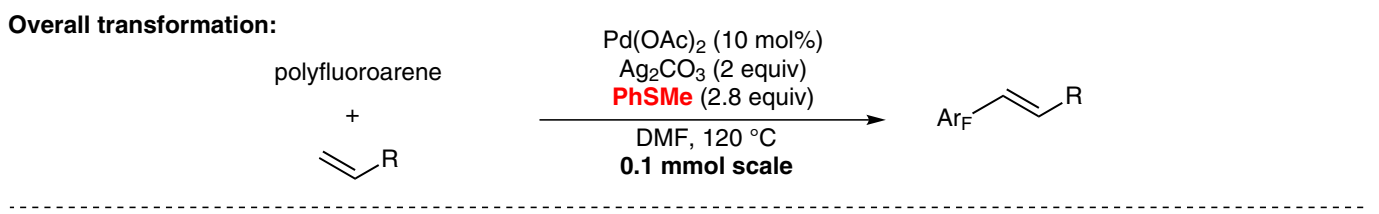<smiles>CC(C)(C)OC(=O)C=Cc1c(F)c(F)c(F)c(F)c1F</smiles><smiles>CCOC(=O)C=Cc1c(F)c(F)c(F)c(F)c1F</smiles><smiles>CCOP(=O)(/C=C/c1c(F)c(F)c(F)c(F)c1F)OCC</smiles><smiles>Fc1c(F)c(F)c(/C=C/c2ccccc2)c(F)c1F</smiles>

$80 \%$ yield, $E / Z=20: 1$<smiles>COc1c(F)c(F)c(/C=C/C(=O)OC(C)(C)C)c(F)c1F</smiles>

$80 \%$ yield, $E / Z=30: 1$<smiles>CCOC(=O)C=Cc1c(F)c(F)c(C(F)(F)F)c(F)c1F</smiles>

$74 \%$ yield, $E / Z=28: 1$

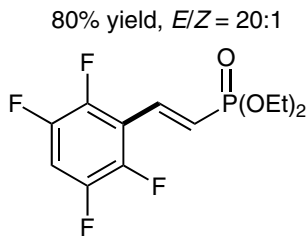

$72 \%$ yield, $E / Z=45: 1$<smiles>Fc1nc(F)c(F)c(/C=C/c2ccccc2)c1F</smiles>

$40 \%$ yield

\section{Competition experiment:}<smiles>Fc1ccc(F)c(F)c1F</smiles><smiles>C=CC(=O)OC(C)(C)C</smiles><smiles>CC(C)(C)OC(=O)C=Cc1c(F)c(F)c(F)c(F)c1F</smiles>
DMF, $120^{\circ} \mathrm{C}$

(1:1 product ratio)<smiles>Fc1c(F)c(F)c(/C=C/c2ccccc2)c(F)c1F</smiles>

Significance: The dehydrogenative Heck reaction represents a more environmentally friendly variant of the classic Nobel prize winning transformation, as it makes use of non-prefunctionalized substrates. Polyfluoroarenes are important structural motifs, and the development of new methods to incorporate them in an efficient manner is an important endeavor. The report represents a rare example of a thioether promoted $\mathrm{C}-\mathrm{H}$ functionalization of electron-deficient arenes.

SYNFACTS Contributors: Mark Lautens, David A. Petrone Synfacts 2014, 10(1), 0062 Published online: 13.12.2013 DoI: 10.1055/s-0033-1340448; Reg-No.: L15813SF
Comment: The authors report a palladium-catalyzed methyl phenyl sulfide promoted direct olefination of polyfluoroarenes. These previously 'unreactive' substrates undergo facile transformation with the specifically chosen sulfur-containing ligand. Products are obtained in good to excellent yields and with high $E / Z$ selectivities. A competition reaction between pentafluorobenzene and both styrene and tert-butyl acrylate show that there is no bias between electron-rich and electron-deficient olefins under the reported conditions. 


\section{Asymmetric Formal Insertion of Diazo Esters into Aryl-CHO Bonds}

Metal-Catalyzed Asymmetric

Synthesis and

Stereoselective

Reactions

\section{Key words}

oxazaborolidines

diazo esters

Roskamp reaction

Selected examples:

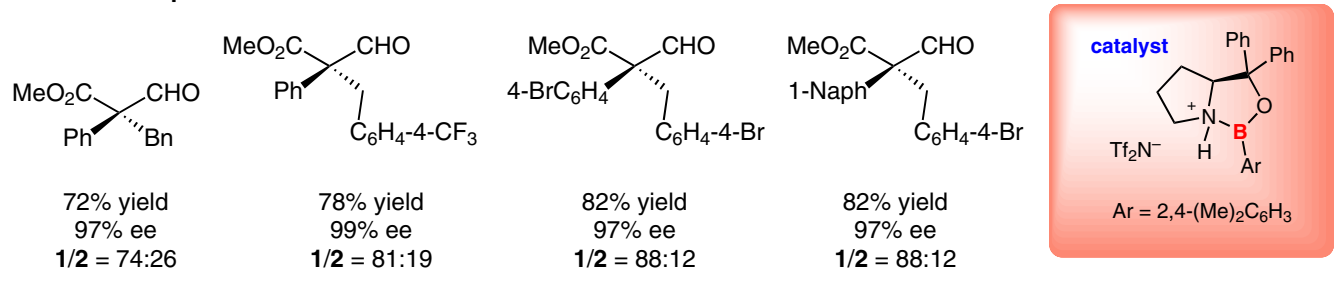

Transition-state model:
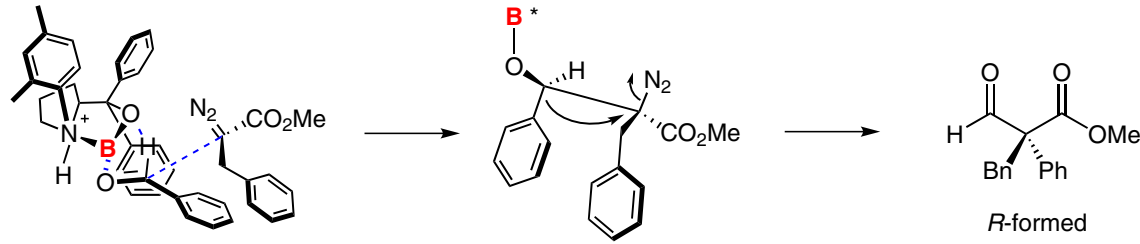

Applications:

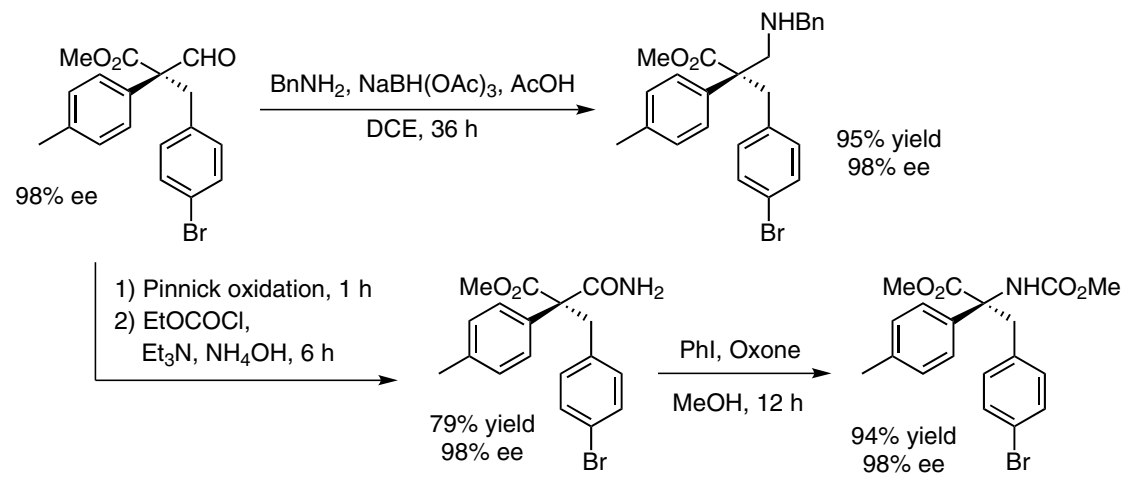

Significance: The authors developed an oxazaborolidinium ion catalyzed asymmetric formal C-C bond insertion of diazo esters into aryl- $\mathrm{CHO}$ bonds to give functionalized acyclic all-carbon $\alpha$ quaternary aldehydes in good yields (up to 83\%) and excellent enantioselectivities (up to 99\%). The products were transformed into synthetically useful $\alpha$-and $\beta$-amino esters with ease.

SYNFACTS Contributors: Hisashi Yamamoto, Mahiuddin Baidya Synfacts 2014, 10(1), 0063 Published online: 13.12.2013 Dol: 10.1055/s-0033-1340457; Reg-No.: H16413SF
Comment: Contrary to the Roskamp reaction, the 1,2-aryl shift is preferred over the 1,2-hydride shift. It is the first catalytic asymmetric report of such a reaction. A variety of diazo esters and aldehydes were explored emphasizing synthetic flexibility. However, the regioselectivities are rather moderate (up to 88:12). Recently, Feng and coworkers reported a similar 1,2-aryl shift for the asymmetric homologation of $\alpha$-keto esters (Angew. Chem. Int. Ed. 2013, 52, 10883). 
Metal-Catalyzed Asymmetric Synthesis and Stereoselective Reactions

\section{Key words}

palladium

bisphosphine ligands

asymmetric hydrogenation
J. CHEN, D. LIU, N. BUTT, C. LI, D. FAN, Y. LIU, W. ZHANG* (SHANGHAi JiAO TONG UNIVERSITY, P. R. OF CHINA)

Palladium-Catalyzed Asymmetric Hydrogenation of $\alpha$-Acyloxy-1-arylethanones

Angew. Chem. Int. Ed. 2013, 52, 11632-11636.

\section{Enantioselective Palladium-Catalyzed Allylic Dearomatization}

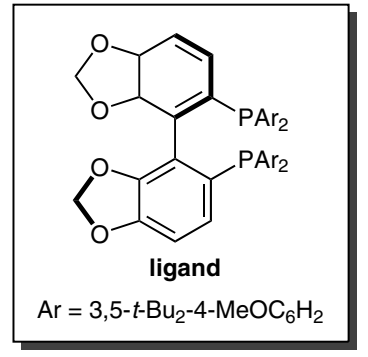

Selected examples:<smiles>CC(C)(C)C(=O)COC(O)c1ccccc1</smiles><smiles>CC(C)(C)C(=O)COC(O)c1ccccc1Cl</smiles><smiles>CC(C)(C)C(=O)COC(O)c1ccc(C(F)(F)F)cc1</smiles><smiles>CC(C)(C)C(=O)COC(O)c1ccco1</smiles>
$>99 \%$ conversion $97 \%$ ee<smiles>COc1ccccc1C(O)OCC(=O)C(C)(C)C</smiles><smiles>O=C(O)OC(O)c1cccc(Cl)c1</smiles><smiles>CC(C)(C)C(=O)CO[C@H](O)c1ccc(C(C)(C)C)cc1</smiles>

$>99 \%$ conversion $96 \%$ ee<smiles>CC(C)(C)C(=O)COC(O)c1cccs1</smiles>

$37 \%$ conversion $95 \%$ ee
Significance: Chiral $\alpha$-acyloxy- 1 -arylethanols are an important class of useful structural motifs (R. S. Bhondwea et al. Bioorg. Med. Chem. Lett. 2012, 22, 3656). The authors report a palladium catalyzed enantioselective reduction of $\alpha$-acyloxy-1arylethanones to access $\alpha$-acyloxy- 1 -arylethanols in high enantioselectivities.
SYNFACTS Contributors: Mark Lautens, Zafar Qureshi Synfacts 2014, 10(1), 0064 Published online: 13.12.2013 DoI: 10.1055/s-0033-1340444; Reg-No.: L15413SF
Comment: The first synthesis of $\alpha$-acyloxy-1arylethanols was achieved using a chiral diamine ligand and $\mathrm{SnCl}_{2}$ (T. Mukaiyama, K. Tomimori, T. Oriyama Chem. Lett. 1985, 1359). Then, the use of enzymatic methods for their synthesis with excellent enantioselectivities but moderate regioselectivity was reported (A. Manzocchi, A. Fiecchi, E. Santaniello J. Org. Chem. 1988, 53, 4405; T. Ema, Y. Sugiyama, M. Fukumoto, H. Moriya, J.-N. Cui, T. Sakai, M. Utaka J. Org. Chem. 1988, 63, 4996; R. Hayakawa, M. Shimizu, T. Fujisawa Tetrahedron Asymmetry 1997, 8, 3201). With a palladium catalyst and a bisphosphine ligand, the authors were able to show excellent selectivities for a variety of substrates. In addition, catalyst loadings could be lowered to 0.2 mol\% without affecting enantioselectivity. 


\section{Mukaiyama Aldol Reaction Catalyzed by Gallium(III) Triflate}

\section{Key words}

\section{gallium}

Mukaiyama aldol reaction

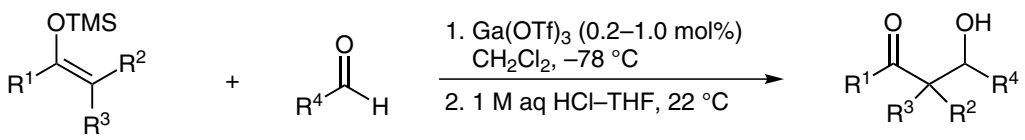

\section{Lewis acids}

Selected examples:<smiles>CC(C(=O)c1ccccc1)C(O)c1ccccc1</smiles>

$80 \%$ yield syn/anti $=85: 15$ $90 \%$ yield syn/anti $=70: 30$ $\mathrm{Ga}(\mathrm{OTf})_{3}(0.01 \mathrm{~mol} \%)$<smiles>CC(C(=O)c1ccccc1)C(O)/C=C/c1ccccc1</smiles>

$66 \%$ yield syn/anti $=82: 18$<smiles>Cc1ccc(C(O)C(C)C(=O)c2ccccc2)cc1</smiles>

$76 \%$ yield $76 \%$ yield
syn/anti $=80: 20$<smiles>CC(C(=O)c1ccccc1)C(O)C(C)(C)C</smiles>

$46 \%$ yield syn/anti $=96: 4$<smiles>CC(C(=O)c1ccccc1)C(O)c1ccccc1Br</smiles>

$76 \%$ yield syn/anti $=18: 82$<smiles>CC(C(=O)c1ccccc1)C(O)c1ccco1</smiles>

$56 \%$ yield syn/anti $=87: 13$
Significance: The authors report a mild method for the diastereoselective Mukaiyama aldol reaction. The process is catalyzed by gallium(III) triflate yielding to the corresponding $\beta$-hydroxy ketones in up to $92 \%$ yield.
Comment: The developed method is an efficient aldol reaction under mild conditions with a very low catalyst loading of gallium(III) triflate (0.01-1.0 mol\%). This is the first example of a metal triflate acting as a safe and stable slow-releasing source of triflic acid in the Mukaiyama aldol reaction. Gallium(III) triflate is a stable, easy-to-handle white solid. 


\section{Gategory}

Metal-Catalyzed Asymmetric Synthesis and Stereoselective Reactions

\section{Key words}

palladium

sulfonic esters

conjugate addition
J. LU, J. YE, W.-L. DUAN* (SHANGHAI INSTITUTE OF ORGANIC CHEMISTRY AND EAST CHINA UNIVERSITY OF SCIENCE AND TECHNOLOGY, SHANGHAI, P. R. OF CHINA)

Palladium-Catalyzed Asymmetric Addition of Diarylphosphines to $\alpha, \beta$-Unsaturated Sulfonic Esters for the Synthesis of Chiral Phosphine Sulfonate Compounds

Org. Lett. 2013, 15, 5016-5019.

\section{Palladium-Catalyzed Asymmetric Synthesis of Phosphine Sulfonates}

$$
\stackrel{\mathrm{R}^{2} \mathrm{O}^{-}}{\stackrel{\text { 1. Pd catalyst }(2.5 \mathrm{~mol} \%)}{\mathrm{PhMe},-60^{\circ} \mathrm{C}, 24 \mathrm{~h}}}
$$
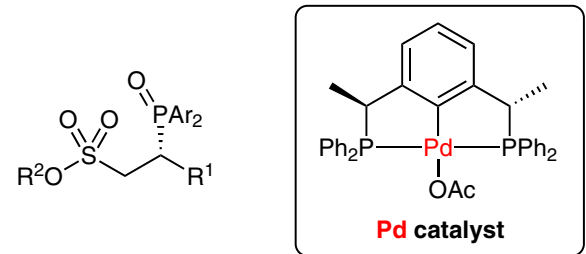

Selected examples:<smiles>O=[PH]c1ccccc1</smiles><smiles>O=[PH](c1ccccc1)[C@H](CS(=O)(=O)OCC(F)(F)F)c1ccccc1</smiles>

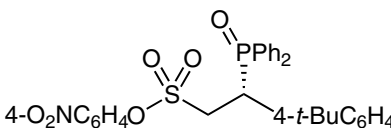<smiles>CCOC(=O)[C@H](CS(=O)(=O)OC(C(F)(F)F)C(F)(F)F)[P+](=O)OCC</smiles>
$88 \%$ yield $97 \%$ ee
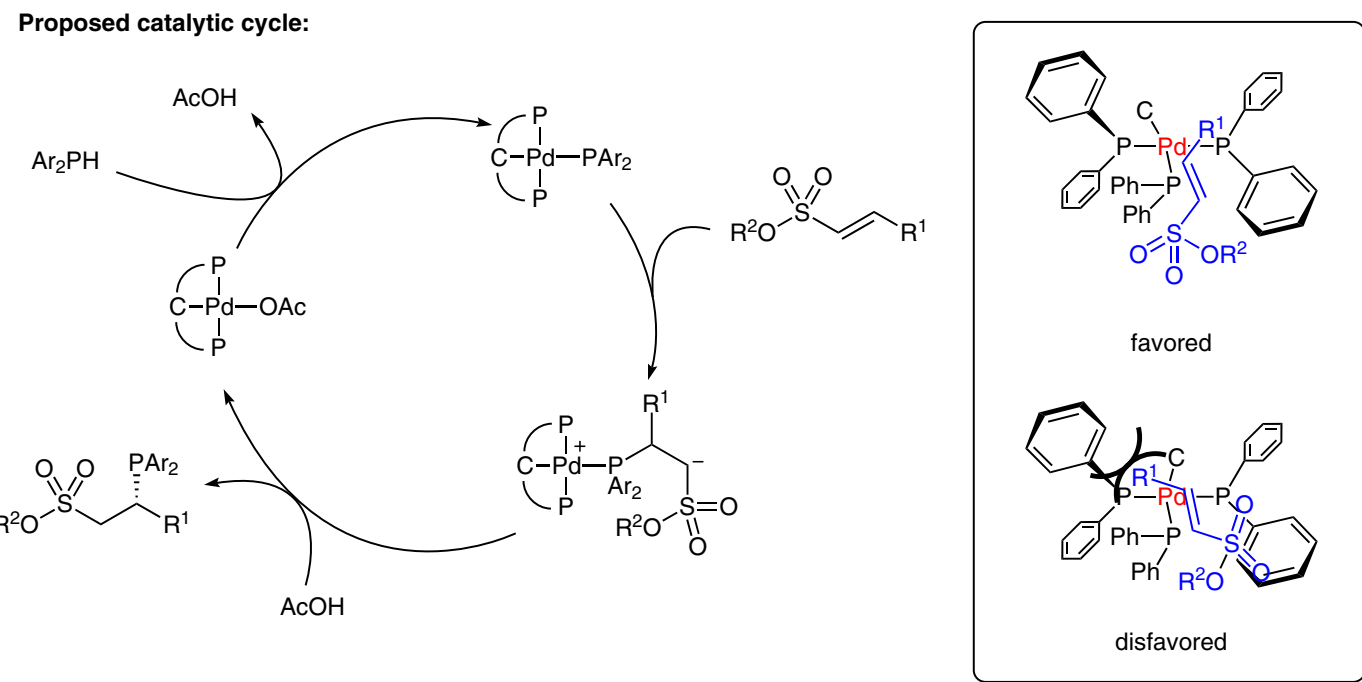

Significance: The authors reported the asymmetric conjugate addition of diarylphosphines to sulfonic esters catalyzed by a pincer-palladium complex. In the presence of an electron-withdrawing group in the sulfonic esters, phosphine sulfonates were obtained in high yields.
Comment: Introducing of heteroatoms into phosphine compounds is interesting since they can be used as ligands in metal-catalyzed transformations. Using this system, a highly enantioselective synthesis of phosphine sulfonates was achieved. The transformation of the product into the palladium complex was also demonstrated.

SYNFACTS Contributors: Hisashi Yamamoto, Yasushi Shimoda 


\section{Enantioselective Hydrogenation of Imines Using Cooperative Catalysis}

Using Cooperative Catalysis

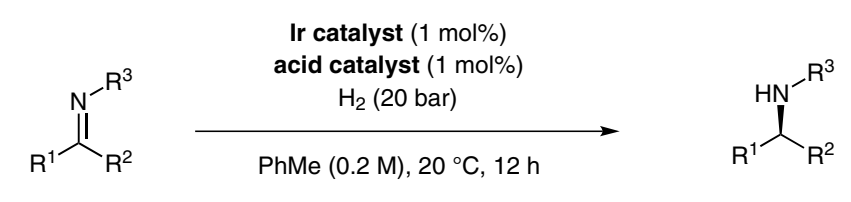

up to $97 \%$ yield

up to $98 \%$ ee

33 examples
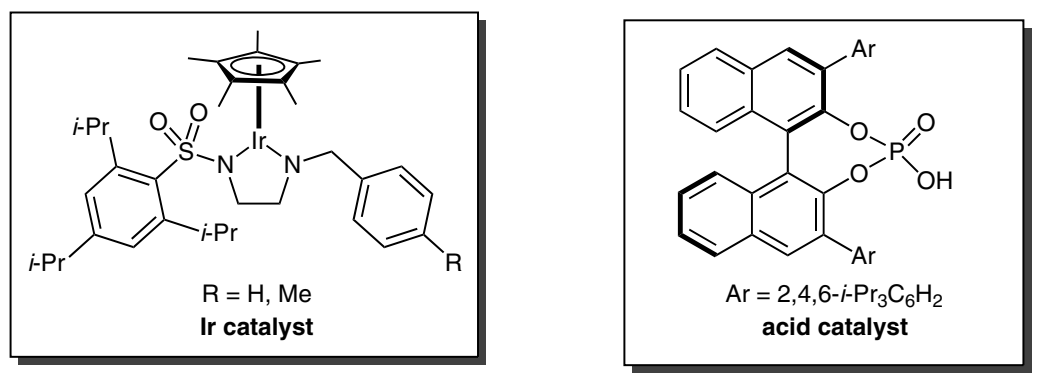

Selected examples:


Significance: Optically active amines are common in many fine chemicals, agrochemicals, and pharmaceuticals. The authors report a cooperative metal-organo catalytic system utilizing a chiral Brønsted acid and an achiral iridium catalyst (see below for a Review on transfer hydrogenation).

Review: C. Zheng, S.-L. You Chem. Soc. Rev. 2012, 41, 2498-2518.
Comment: The authors have reported the cooperative use of a chiral iridium catalyst with a chiral phosphoric acid in the asymmetric hydrogenation of acyclic imines with $\mathrm{H}_{2}$ (J. Am. Chem. Soc. 2008, 130, 14450). Here, they report an achiral iridium catalyst with a chiral phosphoric acid in a similar reaction. Alkyl imines, which are known to be difficult substrates for asymmetric hydrogenation, were shown to be excellent substrates in this system, giving enantioselectivities up to $97 \%$.

\section{Key words}

\section{iridium}

Brønsted acid

cooperative catalysis 


\section{Category}

Metal-Catalyzed Asymmetric Synthesis and Stereoselective Reactions

\section{Key words}

\section{gold}

oxazinoindoles

hydroamination
M. CHIARUCCI, R. MOCCI, L.-D. SYNTRIVANis, G. CERA, A. MAZZANTi, M. BANDini* (UNIVERSITY OF BOLOGNA, ITALY)

Merging Synthesis and Enantioselective Functionalization of Indoles by a Gold-Catalyzed Asymmetric Cascade Reaction

Angew. Chem. Int. Ed. 2013, 52, 10850-10853.

\section{Oxazinoindoles via Gold-Catalyzed Stereoselective Cascade Reaction}

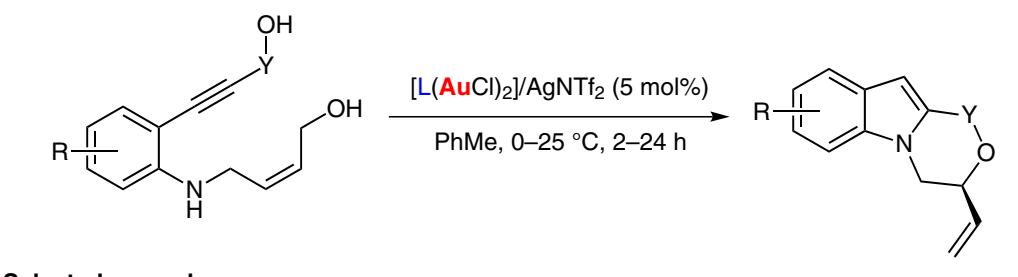<smiles>CCCCc1ccc2c(c1-c1c(P(C)(C)(C)C)ccc3c1OCO3)OCO2</smiles>

Selected examples:<smiles>C=CC1Cn2c(cc3ccccc32)C2(CCCCC2)O1</smiles><smiles>C=CC1Cn2c(cc3ccccc32)CO1</smiles><smiles>C=CC1Cn2c(cc3cc(C)cc(C)c32)C(C)(C)O1</smiles>

$93 \%$ yield $90 \%$ ee $85 \%$ ee $72 \%$ yield

Proposed mechanism:

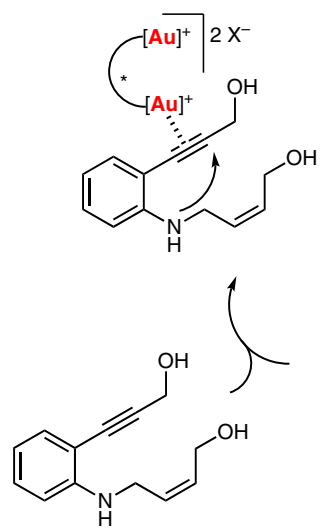<smiles>CC(C)C</smiles>

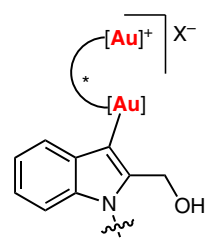
cycle I

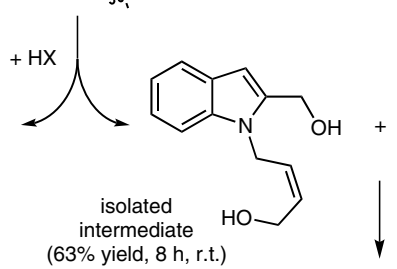<smiles>c1ccccc1</smiles><smiles>CC=CC1Cn2c(cc3ccccc32)CO1</smiles><smiles>c1ccccc1</smiles>
$(63 \%$ yield, $8 \mathrm{~h}$, r.t.

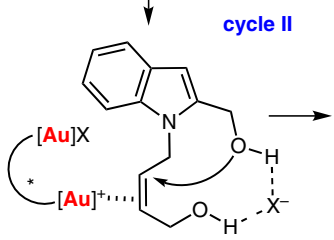

Significance: The authors developed a gold-catalyzed hydroamination followed by an asymmetric nucleophilic allylic substitution cascade to access oxazino[4,3-a]indoles in good yields and enantioselectivities. Owing to pharmacologically active indole alkaloids, this rapid synthesis and asymmetric decoration of the polycyclic indolyl core is highly important.

SYNFACTS Contributors: Hisashi Yamamoto, Mahiuddin Baidya Synfacts 2014, 10(1), 0068 Published online: 13.12.2013 Dol: 10.1055/s-0033-1340458; Reg-No.: H16513SF
Comment: Amazingly, the stereodifferentiating event in this gold-catalyzed asymmetric domino process takes place at the late stage, which is somewhat unusual and more challenging. Extensive mechanistic studies support the stepwise $\mathrm{S}_{\mathrm{N}}{ }^{2}$-type mechanism for the final allylic alkylation ring closure (cycle II). 


\section{Manganese-Catalyzed Enantioselective Alkene Epoxidation}

Metal-Catalyzed Asymmetric

Synthesis and

Stereoselective

Reactions

\section{Key words}

epoxidation

manganese

hydrogen peroxide

\section{Overall transformation:}

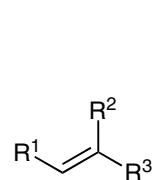

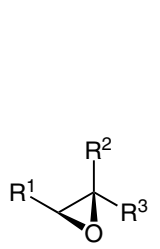

$0.42 \mathrm{mmol}$ scale

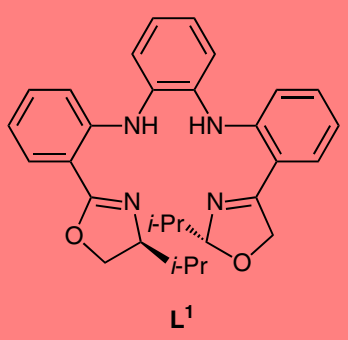

Selected examples:<smiles>CC1(C)CC(=O)c2cc(P)ccc2O1</smiles>

$\mathrm{R}=\mathrm{CN}$

$\mathrm{Cl}$

$\mathrm{NO}_{2}$

$\mathrm{CO}_{2} \mathrm{Me}$

$\mathrm{Ph}$

$\mathrm{CH}_{2} \mathrm{OH}$
95\% yield, $95 \%$ ee $93 \%$ yield, $96 \%$ ee $90 \%$ yield, $96 \%$ ee $93 \%$ yield, $94 \%$ ee $95 \%$ yield, $96 \%$ ee $98 \%$ yield, $94 \%$ ee $96 \%$ yield, $>99 \%$ ee<smiles>[R]c1ccc2c(c1)[C@@H]1O[C@H]1C1(CCCCC1)O2</smiles><smiles>c1ccc2c(c1)C[C@@H]1O[C@H]21</smiles><smiles>c1ccc2c(c1)CC[C@@H]1O[C@H]21</smiles>

$93 \%$ yield, $84 \%$ ee $\quad 99 \%$ yield, $96 \%$ ee

$\mathrm{R}=\mathrm{CN}$ $\mathrm{Br}$

$98 \%$ yield, $90 \%$ ee $91 \%$ yield, $94 \%$ ee $92 \%$ yield, $92 \%$ ee $\begin{array}{ll}\mathrm{CO}_{2} \mathrm{Me} & 97 \% \text { yield, } 90 \% \text { ee } \\ \mathrm{Ph} & 99 \% \text { yield, } 96 \% \text { ee } \\ \mathrm{NHAc} & 99 \% \text { yield, } 98 \% \text { ee }\end{array}$ $\begin{array}{ll}\mathrm{CO}_{2} \mathrm{Me} & 97 \% \text { yield, } 90 \% \text { ee } \\ \mathrm{Ph} & 99 \% \text { yield, } 96 \% \text { ee } \\ \mathrm{NHAc} & 99 \% \text { yield, } 98 \% \text { ee }\end{array}$ $\mathrm{NHAC}$<smiles>[R]C1O[C@@H]1c1ccccc1</smiles>
$\mathrm{R}=\mathrm{H} \quad 98 \%$ yield, $47 \%$ ee
$\mathrm{R}=\mathrm{Ph} \quad 95 \%$ yield, $92 \%$ ee

Gram-scale synthesis of the chiral drug (S)-levcromakalim:
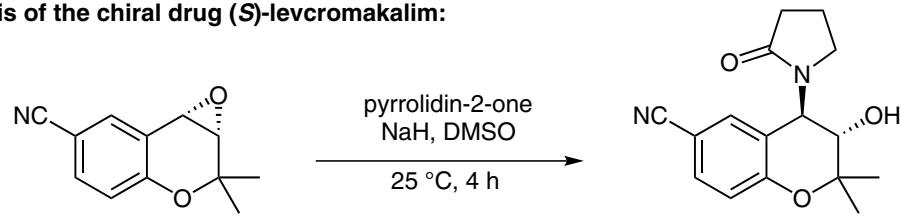

$61 \%$ yield, $97 \%$ ee

Significance: Epoxides are an important class of molecules and serve frequently as intermediates in complex molecule synthesis. Many highly effective protocols have been developed for the generation of enantioenriched epoxides by way of transition-metal and organocatalysis. However, not all classes of substrates proceed smoothly with high levels of enantioselectivity under the published methods, and therefore the development of new and robust epoxidation methods is of great interest.
Comment: Gao and co-workers report the use of Jacobsen-type manganese-catalyzed epoxidation of chromenes, indenes, styrenes, and dihydronapthalenes using a porphyrin-inspired tetradentate ligand. Products are obtained in excellent yields and enantioselectivities using a low catalyst loading (0.2 mol\%). This environmentally friendly method makes use of two equivalents of $\mathrm{H}_{2} \mathrm{O}_{2}$ as the terminal oxidant. The authors were able to extend their methodology to the synthesis of the chiral drug (S)-levcromakalim. 